\title{
Long-term real-time chemical characterization of submicron aerosols at Montsec (southern Pyrenees, 1570 m a.s.l.)
}

\author{
A. Ripoll ${ }^{1,2}$, M. C. Minguillón ${ }^{1}$, J. Pey ${ }^{3}$, J. L. Jimenez ${ }^{4}$, D. A. Day ${ }^{4}$, Y. Sosedova ${ }^{5}$, F. Canonaco ${ }^{5}$, A. S. H. Prévôt ${ }^{5}$, \\ X. Querol ${ }^{1}$, and A. Alastuey ${ }^{1}$ \\ ${ }^{1}$ Institute of Environmental Assessment and Water Research (IDAEA-CSIC), Jordi Girona 18-26, 08034, Barcelona, Spain \\ ${ }^{2}$ Department of Astronomy and Meteorology, Faculty of Physics, University of Barcelona, Martí i Franquès 1, \\ 08028, Barcelona, Spain \\ ${ }^{3}$ Aix-Marseille Université, CNRS, LCE FRE 3416, Marseille, 13331, France \\ ${ }^{4}$ Department of Chemistry and Biochemistry, and Cooperative Institute for Research in the Environmental Sciences (CIRES), \\ University of Colorado at Boulder, CO 80309, USA \\ ${ }^{5}$ Paul Scherrer Institute, Laboratory of Atmospheric Chemistry, 5232 Villigen PSI, Switzerland
}

Correspondence to: A. Ripoll (anna.ripoll@idaea.csic.es)

Received: 16 October 2014 - Published in Atmos. Chem. Phys. Discuss.: 19 November 2014

Revised: 24 February 2015 - Accepted: 25 February 2015 - Published: 16 March 2015

\begin{abstract}
Real-time measurements of inorganic (sulfate, nitrate, ammonium, chloride and black carbon $(\mathrm{BC})$ ) and organic submicron aerosols (particles with an aerodynamic diameter of less than $1 \mu \mathrm{m}$ ) from a continental background site (Montsec, MSC, $1570 \mathrm{~m}$ a.s.l.) in the western Mediterranean Basin (WMB) were conducted for 10 months (July 2011-April 2012). An aerosol chemical speciation monitor (ACSM) was co-located with other online and offline $\mathrm{PM}_{1}$ measurements. Analyses of the hourly, diurnal, and seasonal variations are presented here, for the first time, for this region.

Seasonal trends in $\mathrm{PM}_{1}$ components are attributed to variations in evolution of the planetary boundary layer (PBL) height, air mass origin, and meteorological conditions. In summer, the higher temperature and solar radiation increases convection, enhancing the growth of the PBL and the transport of anthropogenic pollutants towards high altitude sites. Furthermore, the regional recirculation of air masses over the WMB creates a continuous increase in the background concentrations of $\mathrm{PM}_{1}$ components and causes the formation of reservoir layers at relatively high altitudes. The combination of all these atmospheric processes results in a high variability of $\mathrm{PM}_{1}$ components, with poorly defined daily patterns, except for the organic aerosols (OA). OA was mostly composed (up to $90 \%$ ) of oxygenated organic aerosol (OOA), split in two types: semivolatile (SV-OOA) and low-volatility
\end{abstract}

(LV-OOA), the rest being hydrocarbon-like OA (HOA). The marked diurnal cycles of OA components regardless of the air mass origin indicates that they are not only associated with anthropogenic and long-range-transported secondary OA (SOA) but also with recently produced biogenic SOA.

Very different conditions drive the aerosol phenomenology in winter at MSC. The thermal inversions and the lower vertical development of the PBL leave MSC in the free troposphere most of the day, being affected by PBL air masses only after midday, when the mountain breezes transport emissions from the adjacent valleys and plains to the top of the mountain. This results in clear diurnal patterns of both organic and inorganic concentrations. OA was also mainly composed $(71 \%)$ of OOA, with contributions from HOA (5\%) and biomass burning OA (BBOA; $24 \%)$. Moreover, in winter sporadic long-range transport from mainland Europe is observed.

The results obtained in the present study highlight the importance of SOA formation processes at a remote site such as MSC, especially in summer. Additional research is needed to characterize the sources and processes of SOA formation at remote sites. 


\section{Introduction}

Earth's climate system is modulated by atmospheric aerosols. Submicron particles $(<1 \mu \mathrm{m}$ in aerodynamic diameter) play a dominant role in both cloud formation and scattering or absorbing solar radiation (IPCC, 2013). The complexity of aerosol sources and processes results in an uncertainty in the radiative forcing of climate. Aerosol optical properties are connected to direct and indirect climate forcing effects, and they are dependent on particle composition. Moreover, aerosol composition may provide valuable information on aerosol sources and processes. Consequently, long-term measurements of $\mathrm{PM}_{1}$ chemical composition are needed to better understand aerosol sources, to quantify their lifetime in the atmosphere and to constrain the uncertainties of their climatic influence.

Long-term $\mathrm{PM}_{1}$ chemical composition measurements are relatively scarce both offline and online. In the last decade, online $\mathrm{PM}_{1}$ chemical composition measurements have been performed using aerosol mass spectrometers (AMS) at a number of locations. Measurements of online chemical composition are useful to study hourly variations and daily patterns. Most of these studies, however, correspond to shortterm measurement campaigns (typically a month) (e.g., Crippa et al., 2014; Jimenez et al., 2009; Lanz et al., 2010; $\mathrm{Ng}$ et al., 2010; Zhang et al., 2007) given the intensive instrument maintenance required and the need of highly qualified personnel for a good quality data set.

In contrast to the use of the AMS in relatively short campaigns, the more recently developed Aerodyne aerosol chemical speciation monitor (ACSM) is becoming a widely used online instrument for long-term measurements of $\mathrm{PM}_{1}$ chemical composition (Budisulistiorini et al., 2013; Canonaco et al., 2013; Carbone et al., 2013; Petit et al., 2014; Tiitta et al., 2014). The ACSM is built upon the same technology as the AMS, in which an aerodynamic particle focusing lens is combined with high vacuum thermal particle vaporization, electron impact ionization, and mass spectrometry. Modifications in the ACSM design (e.g., lack of particle sizing chamber and components, and use of a simple and compact RGA mass spectrometer detector), however, allow it to be smaller, less costly, and simpler to operate than the AMS ( $\mathrm{Ng}$ et al., 2011c). The ACTRIS (Aerosols, Clouds, and Trace gases Research InfraStructure) European network is evaluating the use of the ACSM as a reliable instrument, which will provide the opportunity to study long-term data sets of $\mathrm{PM}_{1}$ chemical composition across the continent.

Recent publications have investigated most of the existing worldwide AMS databases (e.g., Crippa et al., 2014; Jimenez et al., 2009; Lanz et al., 2010; Ng et al., 2010; Zhang et al., 2007) and reflected a prevalence of organic aerosols (20$90 \%$ ) in the submicron fraction, largely independent of the region and type of environment. However, our knowledge on organic aerosol (OA) formation, sources, and atmospheric processing is still very incomplete, especially for secondary organic aerosol (SOA) formed from chemical reactions of gas-phase species (e.g., Donahue et al., 2014; Hallquist et al., 2009; Kroll and Seinfeld, 2008; Robinson et al., 2007; Volkamer et al., 2006). Recent progress has been made in identifying primary organic aerosol (POA) sources (e.g., Elbert et al., 2007; Zhang et al., 2005), but significant gaps still remain in our understanding on the atmospheric evolution of POA after emission (de Gouw and Jimenez, 2009). For these reasons, OA measurements and analysis are required to better understand its chemical evolution in the atmosphere.

The lack of long-term online $\mathrm{PM}_{1}$ chemical composition measurements is especially evident in the western Mediterranean Basin (WMB), which is characterized by particular atmospheric dynamics strongly influenced by its topography (Jorba et al., 2013; Millan et al., 1997). Over this region, arrival of natural and anthropogenic aerosols as a result of long-range transport from Africa and Europe is frequent (e.g., Pey et al., 2013; Querol et al., 2009; Ripoll et al., 2014; Rodríguez et al., 2001) and accumulation and recirculation processes are frequently observed (Rodriguez et al., 2002). The sources and meteorological controls of PM in the regional background of the WMB have been recently investigated during the DAURE (Determination of the sources of atmospheric Aerosols in Urban and Rural Environments in the western Mediterranean) study (Pandolfi et al., 2014a) using an AMS and ${ }^{14} \mathrm{C}$ analyses (Crippa et al., 2014; Minguillón et al., 2011). Furthermore, Ripoll et al. (2015) studied the $\mathrm{PM}_{1}$ and $\mathrm{PM}_{10}$ chemical composition with daily time resolution in the continental and regional background environments in the WMB. In that study, a higher mineral contribution was identified in the continental background due to the preferential transport of African dust at high altitude layers and to the increased regional dust resuspension enhanced by the drier surface and higher convection. Nevertheless, aerosol chemical characterization with higher time resolution is needed to study the origin of specific PM components and the local and/or regional processes, in particular to exploit the information contained in diurnal cycles that is typically not accessible with offline measurements.

In this study we deployed an ACSM at a high altitude site (Montsec, $1570 \mathrm{~m}$ a.s.1.) in the NE of the Iberian Peninsula $\left(42^{\circ} 03^{\prime} \mathrm{N}, 0^{\circ} 44^{\prime} \mathrm{E}\right)$, representative of the continental background conditions of the WMB (Ripoll et al., 2014). This environment is under free tropospheric (FT) influence most of the time, although it is exposed to regional pollutants during the summer time and/or under the influence of mountain breezes, and it is affected by transboundary incursions of natural and anthropogenic aerosols from Europe and North Africa (Ripoll et al., 2014, 2015). Co-located online and offline $\mathrm{PM}_{1}$ measurements were also carried out to complement the ACSM data set. Hence, the work presented here interprets the real-time variation of inorganic and organic submicron components during 10 months (July 2011-April 2012), and the types of OA are also studied. Special emphasis is placed on the analysis of the diurnal pattern and seasonal 
variations of chemical components and the main factors influencing these variations.

\section{Methodology}

\subsection{Sampling site}

The Montsec site (MSC) is located on the highest part of the Montsec d'Ares mountain, at an altitude of $1570 \mathrm{~m}$ a.s.l., in a plain near the edge of a $1000 \mathrm{~m}$ cliff to the south, with no wind obstructions present around. It is located in the NE of the Iberian Peninsula $\left(42^{\circ} 03^{\prime} \mathrm{N}, 0^{\circ} 43^{\prime} \mathrm{E}\right), 50 \mathrm{~km} \mathrm{~S}$ of the Pyrenees and $140 \mathrm{~km}$ NW of Barcelona (Fig. S1 in the Supplement.). A detailed description of this site can be found in Ripoll et al. (2014). This station is a member of the GAW (global atmospheric watch) network as a regional station named MSA.

The daily classification of atmospheric episodes affecting MSC was made following the procedure described by Ripoll et al. (2014) using the HYSPLIT (Hybrid Single Particle Lagrangian Integrated Trajectory Model) model from the NOAA Air Resources Laboratory (ARL). Air masses reaching MSC are mainly from the Atlantic (62\% of the days) throughout the year. From March to October, North African (NAF) episodes are more frequent (17\% of the days) and are very often alternated with the summer regional (SREG) scenarios (12\% of the days). The winter regional (WREG) scenarios are detected from October to March $(11 \%$ of the days), as well as the European (EU) episodes (11\% of the days). Conversely, the Mediterranean (MED) episodes are detected sporadically (4\% of the days).

The boundary layer height was calculated using the Global Data Assimilation System (GDAS1) model from the NOAA Air Resources Laboratory (http://www.ready.noaa. gov/READYamet.php) (Fig. 1).

\subsection{ACSM sampling and data analysis}

The ACSM (Aerodyne Research Inc.) was measuring continuously from July 2011 to April 2012. The ACSM provides real-time mass concentration of submicron particulate organics, nitrate, sulfate, ammonium and chloride via thermal vaporization and electron impact ionization, with detection by a quadrupole mass spectrometer ( $\mathrm{Ng}$ et al., 2011c). The mass concentration of a given species is determined from the sum of the ion signals at each of its mass spectral fragments and its ionization efficiency (IE) (Canagaratna et al., 2007). Since calibration of IEs for all species is not feasible, the relative ionization efficiency (RIE) (compared to that of nitrate) is used (Jimenez et al., 2003). The ammonium nitrate calibration described by $\mathrm{Ng}$ et al. (2011b) was performed using an atomizer (TSI, Constant Output Atomizer model 3076) for primary aerosol generation, followed by a silica gel diffusion dryer, a differential mobility analyzer (DMA) model TSI 3081, and a condensation particle counter (CPC, TSI 3772).
Monodisperse $300 \mathrm{~nm}$ ammonium nitrate aerosol particles were used, covering a range of nitrate concentrations from 2 to $15 \mathrm{\mu g} \mathrm{m}^{-3}$. Several calibrations were conducted throughout the sampling period, and average values of $2.2 \times 10^{-11}$ for nitrate IE and 5.4 for RIE for ammonium were used for the whole data set. The RIE values used in this study for the rest of the species were those usually applied in AMS ambient concentrations: 1.4 for OA and 1.1, 1.2, and 1.3 for nitrate, sulfate, and chloride, respectively (Canagaratna et al., 2007). RIE for sulfate was experimentally determined 1 year later and was found to be 1.26 , although the default value was used for the current data set. A time resolution of $62 \mathrm{~min}$ was used as a result of 12 scans (one open and one filtered) per data point with a scan speed of $1 \mathrm{~s} \mathrm{amu}^{-1}$.

The ACSM data were analyzed with the standard ACSM data analysis software version 1.5.3.2 (Aerodyne Research Inc.) written in Igor Pro 6 (WaveMetrics, Inc., Lake Oswego, OR, USA). As the ACSM was measuring continuously for a long time, the standard correction for instrument sensitivity drifts was applied to the data set based on the inlet pressure and $N_{2}$ signal. Finally, mass concentrations were corrected using a collection efficiency (CE) to account for the particle bounce of aerosols on the vaporizer. The compositiondependent CE was calculated as described by Middlebrook et al. (2012) and was close to 0.45 for most of the time. Since for most ambient studies a $0.5 \mathrm{CE}$ value is found to be representative with data uncertainties generally within $\pm 20 \%$ (Canagaratna et al., 2007) and since our ACSM concentrations using $\mathrm{CE}=0.5$ were in good agreement with concentrations from other co-located instruments, a CE of 0.5 was used.

The organic components were further investigated by applying the Multilinear Engine (ME-2) (Paatero, 1999) to the organic mass spectra. With the ME-2, the user can introduce a priori information about sources with the so-called $a$ value approach. Hence, the user inputs one or more factor profiles and a constraint defined by the $a$ value, which determines the extent to which the output profile can differ from the profile fed to the model. The source apportionment of OA was performed applying ME-2 using the custom software tool of Source Finder (SoFi) version 4.8 developed by Canonaco et al. (2013). The ME-2 analysis was carried out separately for the summer period (14 July 2011-24 September 2011) and the winter period (10 January 2012-7 March 2012). Only $m / z \leq 100$ were used for source apportionment of OA because (a) the signals of $m / z>100$ account for a minor fraction of the total organic mass (on average, $2 \%$ ), (b) the $m / z>100$ have larger uncertainties, and (c) the large interference of naphthalene signals (used for $m / z$ calibration of the ACSM) at these $m / z$ (e.g., $m / z 127,128$, and 129) (Sun et al., 2012). 


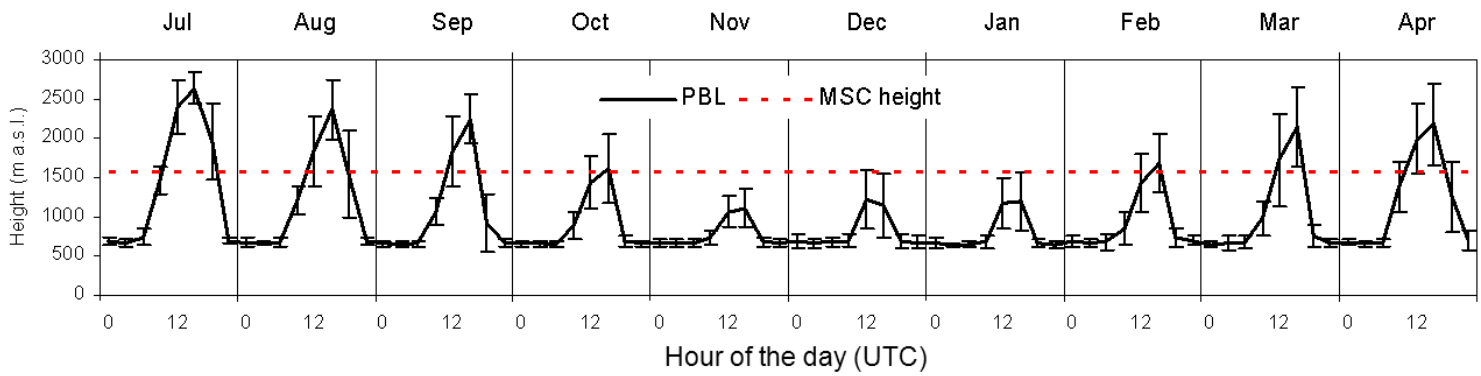

Figure 1. Diurnal variation of the boundary layer height (computed with HYSPLIT model) averaged for each month during the study period at Montsec. Variation bars indicate \pm standard deviation.

\subsection{Co-located measurements used in this study}

MSC has been permanently equipped with aerosol monitoring instrumentation since January 2010 and some of these measurements were used in this study. The $24 \mathrm{~h} \mathrm{PM}_{1}$ samples were collected every 4 days on $150 \mathrm{~mm}$ quartz microfiber filters (Pallflex QAT) using high volume samplers $\left(30 \mathrm{~m}^{3} \mathrm{~h}^{-1}\right.$, MCV CAV-A/MSb) equipped with MCV $\mathrm{PM}_{1}$ cutoff inlets. Daily $\mathrm{PM}_{1}$ mass concentrations were determined by offline gravimetric procedures according to the EN 12341 standard (CEN, 1999), i.e., at $20^{\circ} \mathrm{C}$ temperature and $50 \%$ relative humidity. Furthermore, $\mathrm{PM}_{1}$ chemical composition was obtained as described by Ripoll et al. (2015) using inductively coupled plasma atomic emission spectroscopy (ICP-AES) and mass spectrometry (ICP-MS) for major and trace elements, respectively, ion high performance liquid chromatography (HPLC) and selective electrode for ions concentrations, and the thermal-optical method (using the EUSSAR 2 protocol) for elemental carbon (EC) and organic carbon (OC) concentrations. Real-time $\mathrm{PM}_{1}$ mass concentrations were continuously measured by an optical particle counter (OPC, model GRIMM 1.107 calibrated with a different latex PSL refraction index 1.59). $\mathrm{PM}_{1} 30$ min data were averaged daily and subsequently corrected by comparison with $24 \mathrm{~h}$ standard gravimetric mass measurements. The absorption coefficient was measured continuously at $637 \mathrm{~nm}$ using a multi-angle absorption photometer (MAAP, model 5012, Thermo). Equivalent black carbon (BC) mass concentrations (Petzold et al., 2013) were calculated by the MAAP instrument software by dividing the measured absorption coefficient $\sigma_{\text {ap }}(\lambda)$ by $6.6 \mathrm{~m}^{2} \mathrm{~g}^{-1}$, which is the instrument default mass absorption cross section (MAC) at $637 \mathrm{~nm}$ (Müller et al., 2011; Petzold and Schönlinner, 2004). Particle scattering $\left(\sigma_{\mathrm{sp}} ; 0-360^{\circ}\right)$ and hemispheric backscattering $\left(\sigma_{\mathrm{bsp}} ; 90\right.$ $\left.270^{\circ}\right)$ coefficients at three wavelengths $(450,525,635 \mathrm{~nm})$ were measured with a LED-based integrating nephelometer (model Aurora 3000, ECOTECH Pty, Ltd, Knoxfield, Australia).

Finally, all meteorological data were measured by the Catalonian Meteorological Service from the Montsec d'Ares station. Gaseous pollutants $\left(\mathrm{O}_{3}, \mathrm{NO}, \mathrm{NO}_{2}, \mathrm{CO}\right.$ and $\left.\mathrm{SO}_{2}\right)$ were measured using real-time monitors belonging to the Network of Control and Surveillance of Air Quality of the Autonomous Government of Catalonia. $\mathrm{NO}$ and $\mathrm{NO}_{2}$ concentrations were measured using a Thermo Scientific instrument model 42i-TL, CO using a Teledyne 300 EU Gas filter correlation analyzer, $\mathrm{O}_{3}$ using a MCV 48AV UV photometry analyzer, and $\mathrm{SO}_{2}$ using a Teledyne $100 \mathrm{EU}$ UV fluorescence analyzer.

In addition to these routine measurements, two intensive campaigns were performed in July-August 2011 and January-February 2012. During these intensive campaigns $\mathrm{PM}_{1}$ filters were collected daily and a scanning mobility particle sizer (SMPS) was installed to measure particle number size distribution of mobility diameters of $11-350 \mathrm{~nm}$ in the summer campaign and of $8-450 \mathrm{~nm}$ in the winter campaign. The SMPS system comprises a classifier unit (model TSI 3080) and a differential mobility analyzer (DMA, model TSI 3081) connected to a condensation particle counter (CPC, model TSI 3772). The SMPS data for the winter campaign were also used to estimate the mass concentration to compare with the ACSM data. To this end, the volume size distributions were calculated from the measured particle number distributions assuming sphericity. The total volume concentrations were computed by integrating over the measured particle range and converted to mass concentration using the estimated composition-dependent density, calculated using the chemical composition given by the ACSM and the equation of Salcedo et al. (2006). Average concentrations shown in the whole paper are arithmetic averages unless otherwise specified.

\section{Results and discussion}

\subsection{Submicron aerosol mass concentrations}

In order to establish the consistency of the different measurements during this study, the sum of the ACSM species (i.e., sulfate + nitrate + ammonium $+\mathrm{OA}+$ chloride) and the $\mathrm{BC}$ mass concentrations was compared with the co-located $\mathrm{PM}_{1}$ and light scattering measurements (Fig. 2). The scatter plots of ACSM plus $\mathrm{BC}$ concentrations vs. $\mathrm{PM}_{1}$ con- 


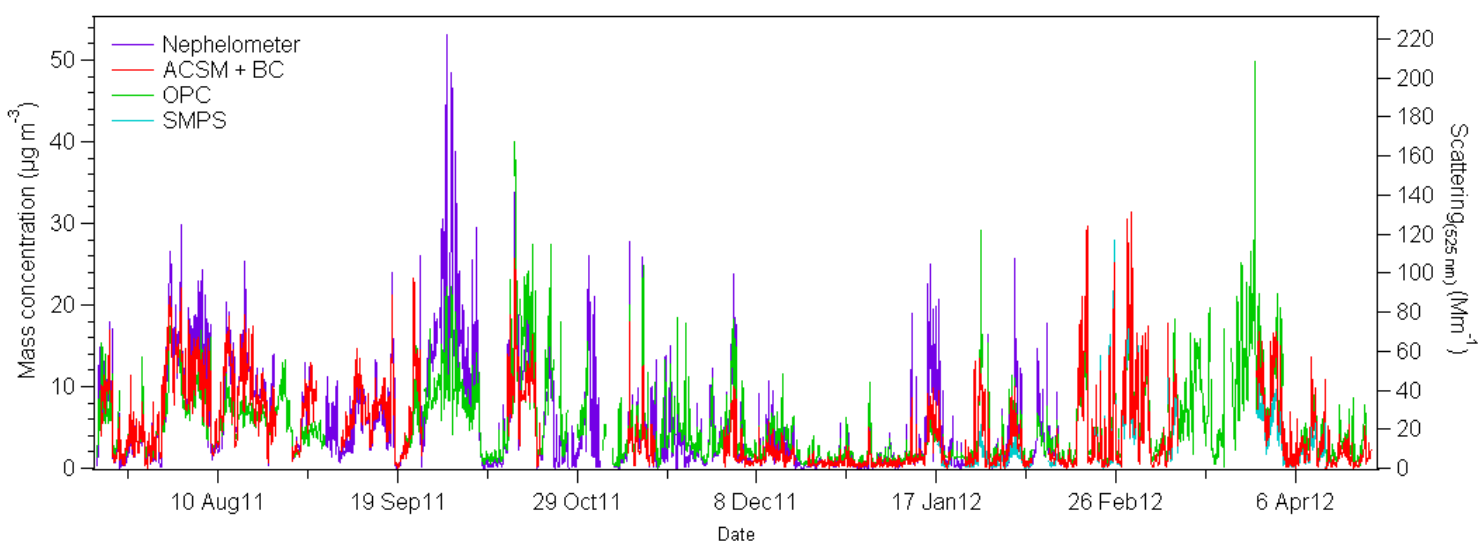

Figure 2. Time series of $\mathrm{PM}_{1}$ total mass from co-located measurements and light scattering at $525 \mathrm{~nm}$.

centrations from the OPC and SMPS showed strong correlations $\left(R^{2}=0.72\right.$ and $R^{2}=0.87$, respectively) and slopes close to unity (slope $=0.94$ and intercept $=0.09$ for the $\mathrm{ACSM}+\mathrm{BC}$ vs. $\mathrm{OPC}$, and slope $=1.21$ and intercept $=0.86$ for the ACSM + BC vs. SMPS) (Fig. 3). The differences in the particle size range measured by the different instruments need to be considered when assessing these comparisons. Moreover, ACSM plus BC concentrations were also highly correlated with light scattering at $525 \mathrm{~nm}$ determined by the nephelometer $\left(R^{2}=0.85\right.$, Fig. 3$)$. The high degree of agreement is also apparent in the time series plots of $\mathrm{PM}_{1}$ shown in Fig. 2.

The average concentration (25th, 50th, 75th percentiles) of the ACSM + BC mass during this study (July 2011-April 2012) was $4.9 \mu \mathrm{g} \mathrm{m}^{-3}\left(0.9,2.8,7.9 \mu \mathrm{g} \mathrm{m}^{-3}\right)$ (Table 1 ), which is similar to the 2010-2012 average reported by Ripoll et al. (2014) from OPC measurements $\left(5.0 \mu \mathrm{g} \mathrm{m}^{-3}\right)$. For the sake of brevity only summer (14 July 2011-24 September 2011) and winter (10 January 2012-7 March 2012) hourly variations will be discussed in the following sections, given that hourly variation in spring was similar to that in summer and that in fall was similar to that in winter. The seasonal average $\mathrm{PM}_{1}$ concentrations were higher in summer $\left(7.5 \mu \mathrm{g} \mathrm{m}^{-3}\left(3.4,7.1,10.5 \mu \mathrm{g} \mathrm{m}^{-3}\right)\right.$, Table 1) than in winter $\left(4.1 \mu \mathrm{g} \mathrm{m}^{-3}\left(0.8,1.7,5.6 \mu \mathrm{g} \mathrm{m}^{-3}\right)\right.$, Table 1). A similar seasonal pattern has been described at other high altitude sites in Europe (e.g., Carbone et al., 2014; Cozic et al., 2008; Freney et al., 2011; Tositti et al., 2013), which are associated with differences in the air mass origin from summer to winter, and also to variations in the planetary boundary layer (PBL) height. The seasonal variation at MSC has been described in detail in recent works (Pandolfi et al., 2014b; Ripoll et al., 2014, 2015), and it has been principally attributed to the seasonal variation of the PBL (Fig. 1). In summer, the stable anticyclonic conditions over this continental area enhance convection, increasing the development of the PBL and favoring the transport of anthropogenic pollutants towards high altitude sites such as MSC. The situation in winter is notably different, as the lower vertical development of the PBL over this area leaves high altitude sites in the FT, isolating MSC from polluted air masses. The seasonal variation of PM concentrations at MSC has been also connected to mesoscale and synoptic processes. At MSC, southern flows and regional recirculation episodes are more frequent in summer, whereas clean Atlantic advections and northeastern winds from mainland Europe are more common in winter (Fig. S2, Table S1) (Pandolfi et al., 2014b; Ripoll et al., 2014, 2015). Moreover, the summer maximum has been ascribed to the more vigorous photochemistry in the atmosphere that enhances the formation of secondary inorganic and organic aerosols (Querol et al., 1999).

\subsection{Submicron aerosol chemical composition}

Concentrations of ACSM species were averaged daily and compared with offline measurements from $24 \mathrm{~h} \mathrm{PM}_{1}$ samples, and all species showed strong correlations $\left(R^{2}\right.$ between 0.77 and 0.96; Fig. S3). Different slopes (ACSM vs. offline measurements) were found for each of the species: 1.12 for sulfate, 1.31 for ammonium and 1.35 for nitrate. The relatively higher slope for nitrate, with respect to sulfate, could be attributed to a sampling negative artifact due to the volatilization of nitrate on the offline samples (Schaap et al., 2004). Ammonium is present as a counterion for sulfate and nitrate and, thus, its slope is in between those of the two species.

The OM-to-OC ratio cannot be determined for ACSMs based on $f_{44}$ following Aiken et al. (2008) as concluded from an intercomparison of 13 ACSMs (Fröhlich et al., 2015). Therefore, the OM-to-OC in the present study was estimated from the slope of OA, measured by ACSM, vs. OC, obtained from offline measurements. This slope was found to be 3.39; however, values of 2.2 are more common for aged aerosol (e.g., Aiken et al., 2008; Minguillón et al., 2011; Takahama et al., 2011). This disagreement of a factor of 1.54 may be attributed to different reasons. A negative volatilization ar- 
Table 1. Diurnal variation of the boundary layer height (computed with HYSPLIT model) averaged for each month during the study period at Montsec. Variation bars indicate \pm standard deviation.

\begin{tabular}{lrrr}
\hline & $\begin{array}{r}\text { Whole period } \\
\left(\mu \mathrm{g} \mathrm{m}^{-3}\right)\end{array}$ & $\begin{array}{r}\text { Summer } \\
\left(\mu \mathrm{g} \mathrm{m}^{-3}\right)\end{array}$ & $\begin{array}{r}\text { Winter } \\
\left(\mu \mathrm{g} \mathrm{m}^{-3}\right)\end{array}$ \\
\cline { 2 - 4 } Period & 14 July 2011-23 April 2012 & 14 July 2011-24 September 2011 & 10 January 2012-7 March 2012 \\
\hline Organics & $2.4(0.5,1.4,3.8)$ & $4.0(2.1,4.0,5.6)$ & $1.9(0.4,1.0,2.6)$ \\
Sulfate & $1.0(0.2,0.5,1.4)$ & $1.9(0.7,1.6,2.7)$ & $0.5(0.1,0.3,0.7)$ \\
Nitrate & $0.7(0.05,0.2,0.7)$ & $0.5(0.1,0.3,0.6)$ & $1.0(0.05,0.2,1.0)$ \\
Ammonium & $0.6(0.09,0.3,0.9)$ & $0.9(0.3,0.8,1.2)$ & $0.5(0.06,0.2,0.7)$ \\
Chloride & $0.05(0.01,0.02,0.05)$ & $0.04(0.01,0.02,0.05)$ & $0.1(0.004,0.02,0.1)$ \\
BC & $0.2(0.04,0.1,0.3)$ & $0.2(0.1,0.2,0.3)$ & $0.2(0.03,0.1,0.2)$ \\
Total & $4.9(0.9,2.8,7.9)$ & $7.5(3.4,7.1,10.5)$ & $4.1(0.8,1.7,5.6)$ \\
\hline
\end{tabular}

tifact may occur in the filters, hence resulting in an underestimation of OC. Alternatively it is possible that the RIE for OA in the ACSM is larger than the value of 1.4 determined for the AMS, a topic currently being investigated by the ACSM manufacturer, which would result in an overestimation of OA. Similar series of intercomparisons with a similar discrepancy for OA have been found for a 1-year data set (June 2012-July 2013) with the same instrument at the Montseny site (Minguillón et al., 2015) and for a recently reported study in Atlanta, USA, by Budisulistiorini et al. (2014). Assuming that the disagreement was due to the overestimation by the ACSM, the OA concentrations were corrected dividing by the disagreement factor (1.54) to compare the results with co-located measurements (Fig. 3). The resulting slopes were very similar and, hence, OA concentrations reported in the present paper were not corrected since further research is needed to better estimate the RIE for OA in the ACSM.

The average of $\mathrm{PM}_{1}$ chemical composition at MSC during this study (July 2011-April 2012) is given in Fig. 4. On average, $\mathrm{OA}$ was the largest $\mathrm{PM}_{1}$ constituent $(50 \%)$, followed by sulfate $(20 \%)$, nitrate $(14 \%)$, ammonium (12\%), BC (4\%) and chloride (1\%). As was the case of $\mathrm{PM}_{1}$ concentrations, all chemical components increased in summer and decreased in winter, with the exception of nitrate (Fig. 4, Table 1). The higher nitrate concentrations in winter than in summer were also observed in other studies in the Mediterranean region (e.g., Pey et al., 2009; Querol et al., 2009; Ripoll et al., 2015) and this variation was attributed to the high volatility of ammonium nitrate at low humidity and high temperature (Zhuang et al., 1999). At MSC, the summer maximum of the rest of PM components has been mainly ascribed to the higher temperature and solar radiation in summer (Table S1), which enhances atmospheric photochemistry, promoting the formation of secondary inorganic and organic aerosols. All these seasonal characteristics are described in detail in Ripoll et al. (2015).

\subsubsection{Summer trends}

Time series of $\mathrm{PM}_{1}$ components during summertime (14 July-24 September 2011) are shown in Fig. 5. Wind direction and wind speed, temperature, precipitation and concentrations of nitrogen oxides, sulfur dioxide, and ozone are also depicted. The daily classification of atmospheric episodes affecting MSC is also illustrated in different background colors. On average, during summer the lowest concentrations of all $\mathrm{PM}_{1}$ components and gases were recorded under the Atlantic advection conditions since these air masses are associated with precipitation, decreased temperature and solar radiation, and strong winds, leading to cleaner atmospheric conditions. Conversely, summer regional episodes lasted for 6-11 consecutive days and led to sustained increases of the background concentrations of sulfate, OA and BC at MSC. Despite the limited ACSM data availability during North African episodes, relatively high concentrations of $\mathrm{PM}_{1}$ components were observed under this type of episodes, especially BC (Fig. 5).

The diurnal cycles of $\mathrm{PM}_{1}$ components, gaseous pollutants and meteorological variables are shown in Fig. 6. The summer concentrations of $\mathrm{PM}_{1}$ components and gases showed no clear diurnal patterns, except for ozone and OA. This lack of defined daily patterns is similar to the findings obtained at the high altitude Puy-de-Dôme station in central France (Freney et al., 2011, the only similar study found at a remote site). For a high altitude site as MSC, the lack of diurnal cycles can be explained by a combination of factors. In summer, the recirculation of air masses over the WMB induced by an abrupt orography (Fig. S1) causes the formation of reservoir layers at any time at relatively high altitudes (Millan et al., 1997; Rodríguez et al., 2003). Moreover, long-range transport from North Africa, which can be more intense at high altitude layers (Ripoll et al., 2015), could also blur the daily patterns since the occurrence of this transport does not depend on the time of the day. These factors result in a lack of well-defined daily patterns but in a high variability of diurnal cycles even within the same type of episode, which is 
a)

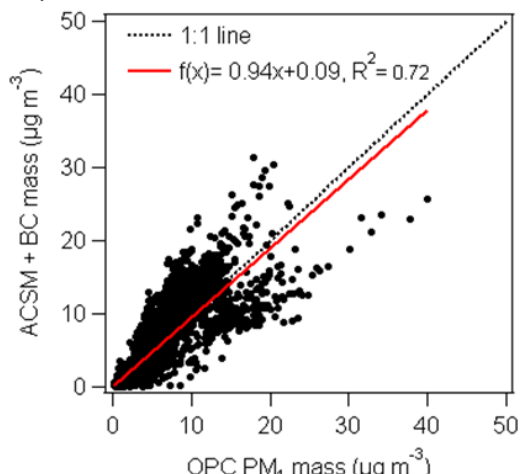

b)

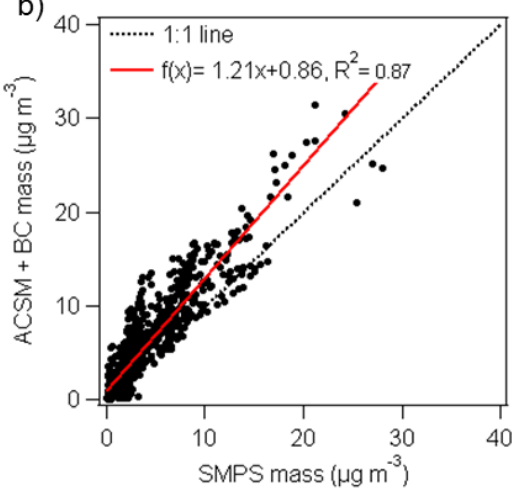

c)

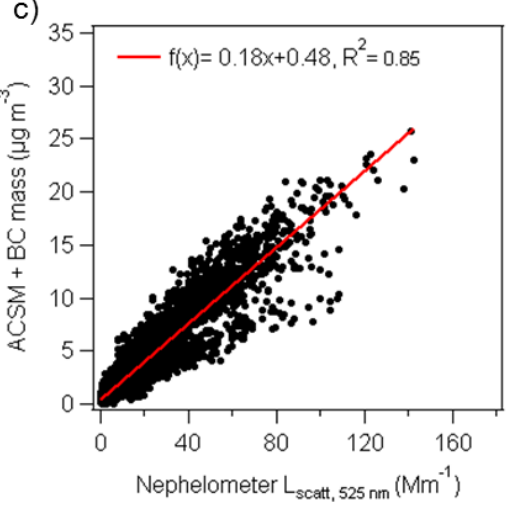

d)

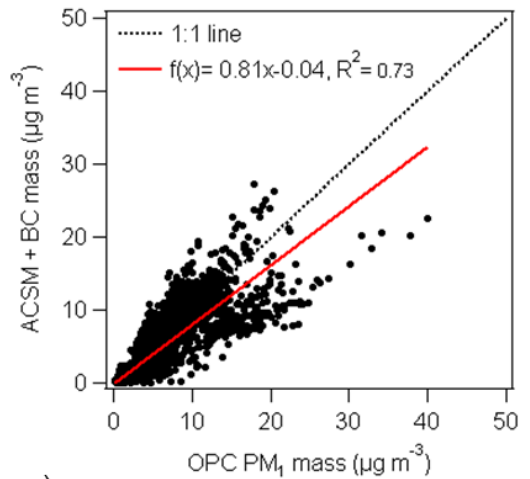

e)
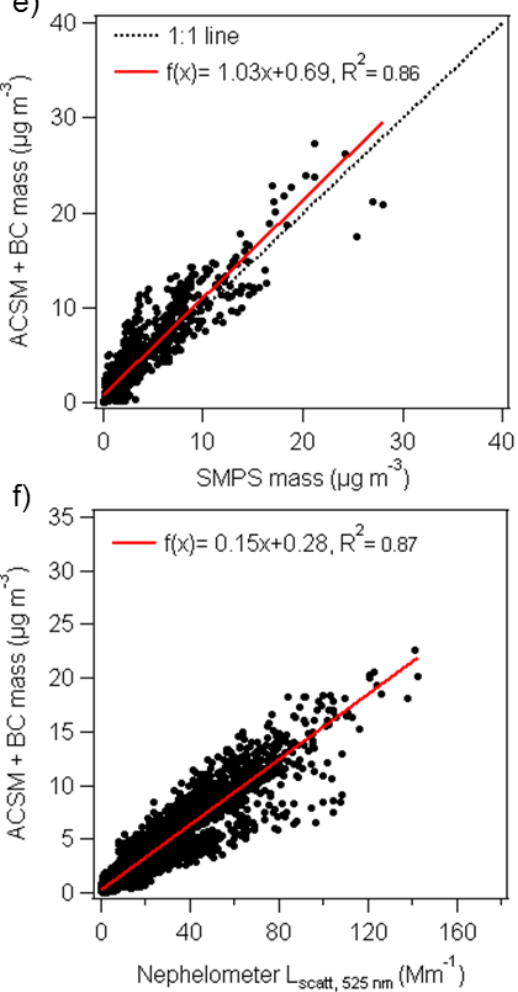

Figure 3. Scatter plots of ACSM plus BC mass vs. $\mathrm{PM}_{1}$ from (a) OPC and (b) SMPS (winter campaign), and vs. light scattering at $525 \mathrm{~nm}$ from (c) nephelometer. Scatter plots of ACSM plus BC mass after dividing OA by 1.54 vs. PM 1 from (d) OPC and (e) SMPS (winter campaign), and vs. light scattering at $525 \mathrm{~nm}$ from (f) nephelometer. Data points correspond to hourly values. Equations and red lines correspond to linear regression fits.

reflected in the similar average daily evolutions and the high standard deviations calculated for the average daily patterns when separated by air mass origin (Fig. S4).

The ozone and OA concentrations had a marked diurnal cycle regardless of the air mass origin (Fig. 6, Fig. S4) in summer. These different daily patterns with respect to the rest of the gases and chemical components points to the fact that ozone and OA variations are strongly influenced by lo$\mathrm{cal} /$ regional processes and not just dominated by long-range transport. Minimum ozone concentrations were recorded between 08:00 and 09:00 UTC (coordinated universal time, which is local time minus $1 \mathrm{~h}$ and local summer time minus $2 \mathrm{~h}$ ), whereas maximum concentrations were measured between 16:00 and 17:00 UTC. In contrast, the highest OA concentrations were observed around 12:00 UTC and the lowest during the night and in the early morning. The ozone variations may influence those of $\mathrm{OA}$, although the complete understanding of the ozone diurnal evolution is outside the scope of this study. The average increase in OA during the day is likely due to the photooxidation of volatile organic compounds (VOCs). Given that MSC is a remote site, in summer VOCs are most likely dominated by local bio- 


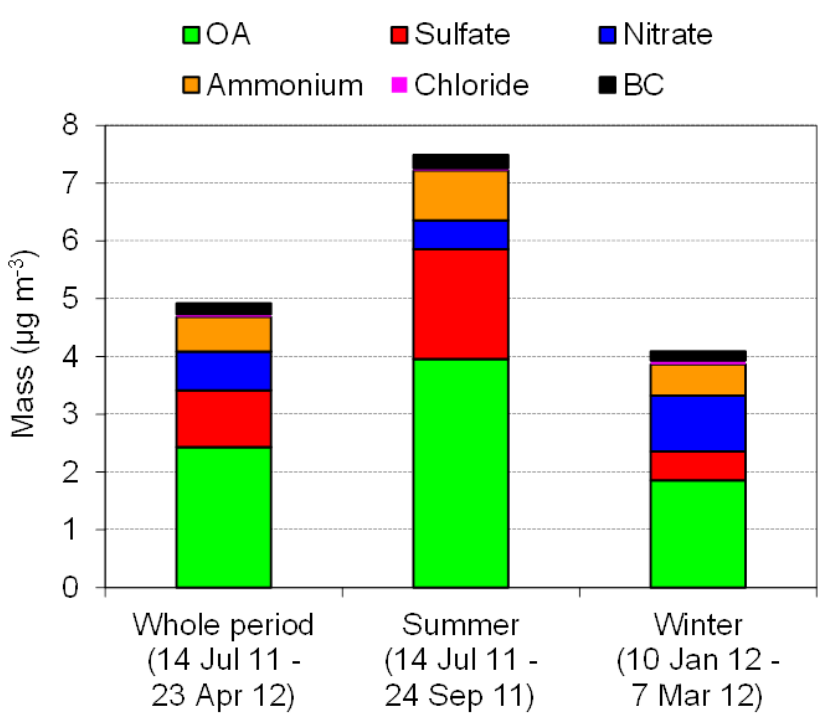

Figure 4. Average concentrations of $\mathrm{PM}_{1}$ chemical species measured at Montsec during the whole study, in summer and in winter.

genic emissions (BVOCs), as it was found in the Mediterranean forested area of Montseny (Seco et al., 2011). Hence, the midday increase is likely due to recently produced biogenic SOA and, to a lesser degree, photooxidation of anthropogenic VOCs.

Despite the marked diurnal cycle of OA regardless of air mass origin, the average increase during the day with respect to average concentrations during the night was higher under summer regional $\left(2.6 \mu \mathrm{g} \mathrm{m}^{-3}\right)$ and North African $\left(3.0 \mu \mathrm{g} \mathrm{m}^{-3}\right)$ episodes than during Atlantic advections $\left(1.3 \mu \mathrm{g} \mathrm{m}^{-3}\right)$ (Fig. S4). This difference could be caused by the higher SOA formation. This is due to the increase in BVOC emissions and atmospheric photooxidation caused by the higher temperature and solar radiation (Paasonen et al., 2013; Seco et al., 2011) under summer regional and North African episodes. Furthermore, under these episodes higher concentrations of ozone were measured, which also favor the formation of SOA (via direct oxidation and also by leading to higher $\mathrm{OH}$ concentrations). The SOA formation registered at MSC is relatively high when compared to other high altitude sites such as Puy-de-Dôme (Freney et al., 2011). This is in agreement with the modeled SOA emissions over Europe, which identified higher SOA concentrations in Mediterranean environments (Bessagnet et al., 2008). This higher SOA formation is probably due to the higher emissions of BVOCs in the Mediterranean forested areas (up to 3 times higher than Boreal forested areas) (Bessagnet et al., 2008; Lang-Yona et al., 2010; Steinbrecher et al., 2009) and the comparable concentrations of tropospheric ozone with other high altitude European sites (Chevalier et al., 2007). On the other hand, the extra formation of SOA under summer regional and North African episodes might also have a contribution from the photooxidation of anthropogenic VOCs since
Atlantic advections are associated with cleaner atmospheric conditions.

\subsubsection{Winter trends}

As in summer, the lowest concentrations of all $\mathrm{PM}_{1}$ components and gases in winter (10 January 2012-7 March 2012) were recorded under the Atlantic advections, whereas the highest were measured when MSC was affected by air masses from mainland Europe and sporadically under regional conditions (Fig. 7). Mediterranean air masses were detected very infrequently and therefore conclusions on their characteristics will not be drawn in the present paper. The relative contribution of different components was similar, with OA representing a somewhat smaller fraction than in summer.

In contrast to what was found in summer, in winter concentrations of most $\mathrm{PM}_{1}$ components and gaseous pollutants showed much clearer diurnal patterns, with a minimum around 07:00 UTC and a maximum between 14:00 and 15:00 UTC (Fig. 6). Similar patterns have been observed at the Puy-de-Dôme station during a winter campaign (Freney et al., 2011). These daily cycles are probably caused by the fact that MSC is located most of the day within the FT in winter, whereas PBL air masses are only injected upwards after midday (Fig. 1) Moreover, thermal inversions are very frequent from 20:00 to 07:00 UTC. These situations prevent the transport of pollutants from the lower populated areas towards higher altitudes, especially at night. During the morning, the thermal inversions dissipate due to the radiative warming of the ground and mountain upslope winds develop (e.g., Henne et al., 2004). These mountain winds transport anthropogenic emissions from the adjacent valleys and plains to the top of the mountain, with a maximum upslope transport in the afternoon. Moreover, the biogenic emissions influence cannot be ruled out as average winter temperatures are high enough for them to occur (Seco et al., 2011; Steinbrecher et al., 2009). Thus, mountain breezes play an important role in determining the diurnal variation of $\mathrm{PM}_{1} \mathrm{com}-$ ponents in winter (Fig. 6), especially under regional conditions. A clear example of the $\mathrm{PM}_{1}$ components' diurnal pattern under winter regional episodes was observed from 22 to 25 February 2012 with $\mathrm{PM}_{1}$ concentrations (and $\mathrm{NO}_{\mathrm{x}}$ ) increasing several fold during the afternoon (Fig. 7).

The study of the daily cycles as a function of air mass origin (Fig. S5) showed clear diurnal patterns under winter regional episodes, as mentioned above, and less marked daily patterns when MSC is affected by Atlantic advections and long-range transport from mainland Europe. Under Atlantic episodes, the concentrations of $\mathrm{PM}_{1}$ components were very low and the standard deviations with respect to the average pattern were quite high, resulting in unclear diurnal patterns compared to those under winter regional conditions. During European episodes, which can be more intense at high altitude layers (Ripoll et al., 2015; Sicard et al., 2011), back- 


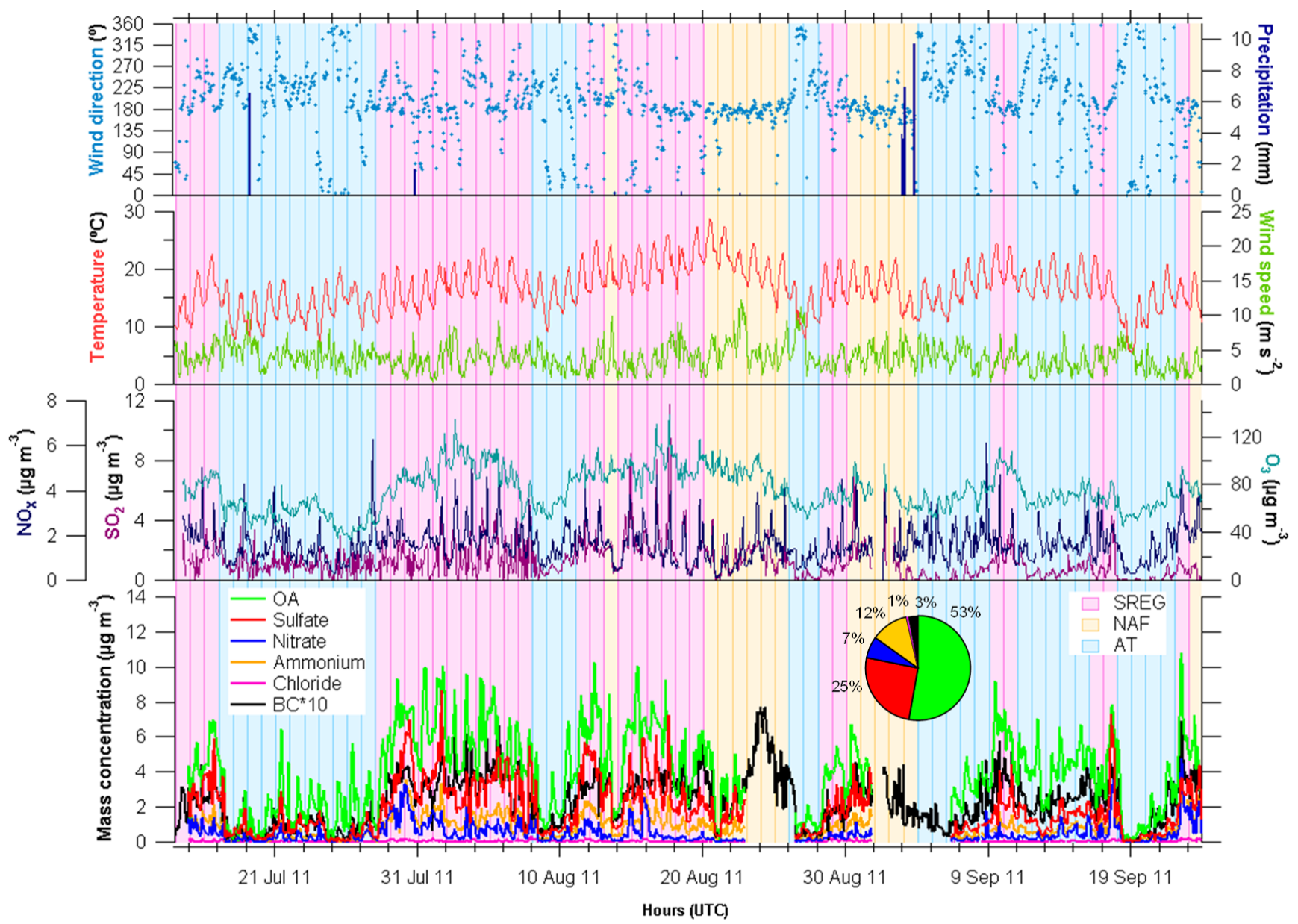

Figure 5. Time series of wind direction, precipitation, temperature, wind speed, concentrations of nitrogen oxides $\left(\mathrm{NO}_{\mathrm{x}}\right)$, sulfur dioxide $\left(\mathrm{SO}_{2}\right)$, ozone $\left(\mathrm{O}_{3}\right)$, and $\mathrm{PM}_{1}$ chemical species (OA, sulfate, nitrate, ammonium, chloride and black carbon (BC)) in summer (14 July 201124 September 2011). Background colors correspond to daily classification of atmospheric episodes (summer regional (SREG), North African (NAF), and Atlantic (AT)) and the pie chart corresponds to the average chemical composition for the summer period.

ground concentrations of $\mathrm{PM}_{1}$ components were higher and the midday increment was lower compared to those under winter regional conditions, resulting in less marked daily patterns. These less-marked diurnal cycles are probably due to the fact that the increase of $\mathrm{PM}_{1}$ components occurs during these episodes regardless of the time of the day. A good example of this less-marked diurnal variation during European episodes was observed from 17 to 19 February 2012 (Fig. 7).

\subsection{Characterization of OA components}

In order to better characterize the profiles of OA components, the ME-2 analysis was performed separately for the summer period (14 July-24 September 2011) and the winter period (10 January 2012-7 March 2012), since OA components are expected to vary throughout the year. The solution of the ME-2 analysis selected for each season was based on several tests, with a different number of factors and different $a$ values, taking into account the correlations with ex- ternal tracers (including nitrate, sulfate, $\mathrm{BC}$ and ozone), the daily patterns of each factor, and the residuals. As a result, a solution of three factors was selected for each season. In summer, a hydrocarbon-like OA (HOA), a semivolatile oxygenated OA (SV-OOA) and a low-volatility oxygenated OA (LV-OOA) (Fig. S6) were resolved. The HOA factor was constrained using an average HOA factor from different data sets (Ng et al., 2011b), with an $a$ value of 0.1. The SV-OOA was characterized by a high $43: 44$ ratio, and the LV-OOA was defined by having a dominant peak at $m / z 44$. In winter the 3 factors identified were HOA, biomass burning OA (BBOA) and OOA (Fig. S6). The HOA and the BBOA factors were constrained based on the profiles from different data sets $(\mathrm{Ng}$ et al., 2011b), with an $a$ value of 0.1 in both factors, and including $\mathrm{BC}$ as an additional variable to the ME-2 analysis. The OOA was characterized by a $43: 44$ ratio between those found for the LV-OOA and the SV-OOA in summer, and by having a dominant peak at $m / z 44$. This high signal 


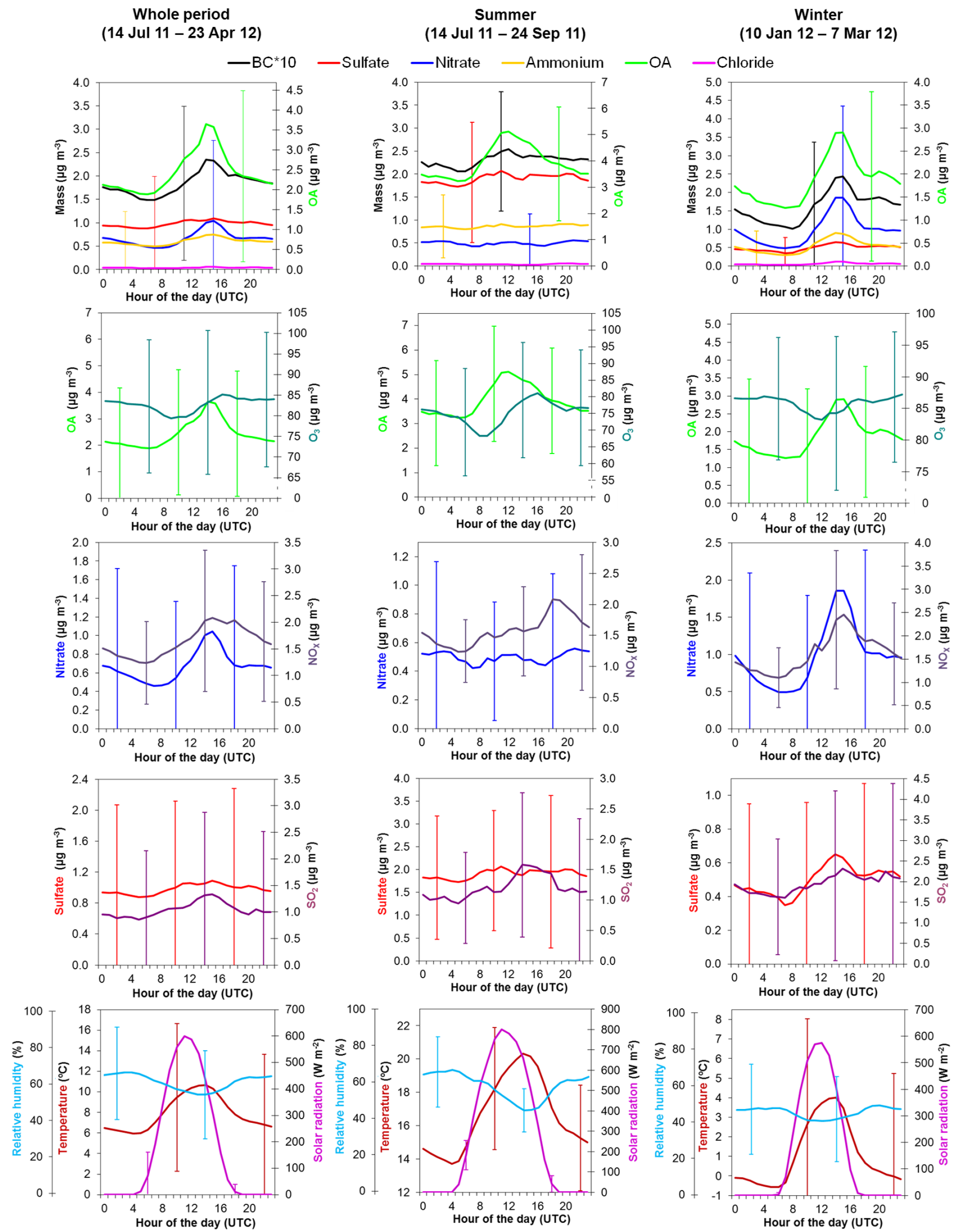

Figure 6. Diurnal cycles of $\mathrm{PM}_{1}$ chemical species (BC, sulfate, nitrate, ammonium, chloride and $\left.\mathrm{OA}\right)$, gaseous pollutants $\left(\mathrm{O}_{3}, \mathrm{NO}_{\mathrm{x}}\right.$, and $\mathrm{SO}_{2}$ ), and meteorological parameters (relative humidity, temperature and solar radiation) averaged for the whole period, summer and winter. Variation bars indicate \pm standard deviation. 


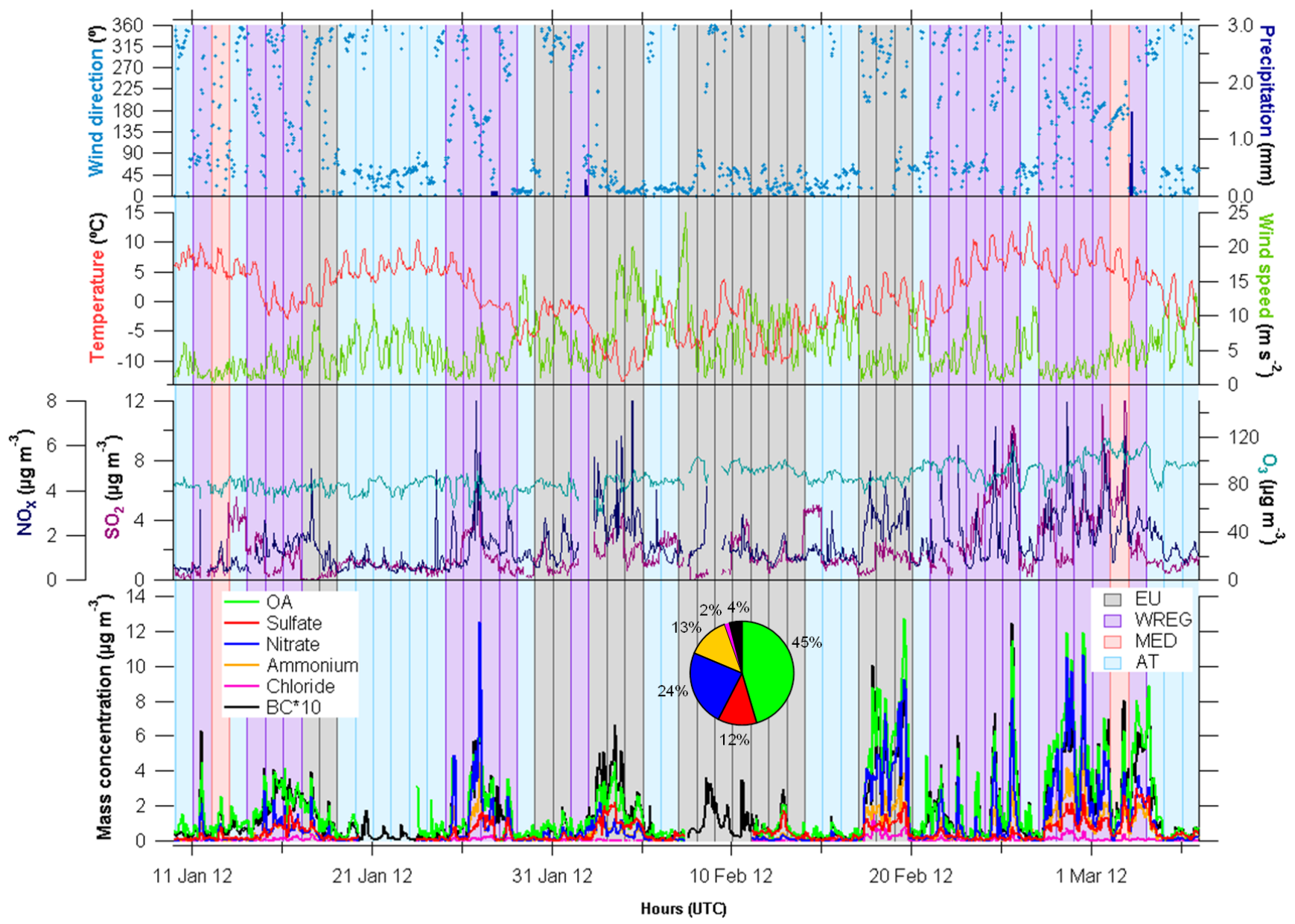

Figure 7. Time series of wind direction (WD) and speed (WS), temperature (T), precipitation (PP), concentrations of $\mathrm{NO}_{\mathrm{x}}, \mathrm{SO}_{2}, \mathrm{O}_{3}$, and $\mathrm{PM}_{1}$ chemical species (organics, sulfate, nitrate, ammonium, chloride and black carbon (BC)) in winter (10 January 2012-7 March 2012). Background colors correspond to daily classification of atmospheric episodes (European (EU), winter regional (WREG), Mediterranean (MED) and Atlantic (AT)) and the pie chart corresponds to the average chemical composition for the winter period.

of $m / z 44$ in the winter OOA indicates a high degree of oxidation and, therefore, a dominant aged character during winter. A solution with four factors in winter was investigated in order to split the OOA into SV-OOA and LV-OOA, but the resulting profiles did not represent two different OOA types, and the time series showed that one of the factors was mainly representing noise. The HOA profiles obtained for the summer and winter periods were similar and showed similar deviations from the $\mathrm{Ng}$ et al. (2011b) spectrum (Fig. S7), since they were constrained with the same anchor HOA profile.

On average, LV-OOA dominated the OA fraction in summer, contributing $64 \%$, followed by SV-OOA (26\%) and the HOA (10\%) (Fig. 8), whereas in winter OOA accounted for $71 \%$, BBOA contributed $24 \%$, and HOA contribution decreased to $5 \%$ (Fig. 9). The high contribution of OOA components confirms the initial hypothesis of MSC organic components being mostly secondary in their origin, and it is in agreement with what was found in other remote sites (Freney et al., 2011; Raatikainen et al., 2010). Furthermore, the origin of OA has been recently investigated in the Mediterranean forested area of Montseny and it has been found that SOA accounted for $91 \%$ (Minguillón et al., 2011). The low contribution of primary organic components at MSC is in agreement with the location, since the primary organic emissions are mixed and oxidized during their transport from industrial and urban areas to the remote site of MSC.

The diurnal cycles of OA components were studied as a function of air mass origin (Fig. 8, 9). A clear daily pattern of OA components was found regardless of the air mass origin, except for Atlantic advections in winter. In summer, the maximum concentrations of LV-OOA and HOA were measured between 12:00 and 13:00 UTC, whereas those of SV-OOA were observed between 11:00 and 12:00 UTC. The LV-OOA has been generally associated with highly oxidized, aged, and long-range-transported aerosol particles (Lanz et al., 2010). Conversely, the SV-OOA has been described as the less oxy- 

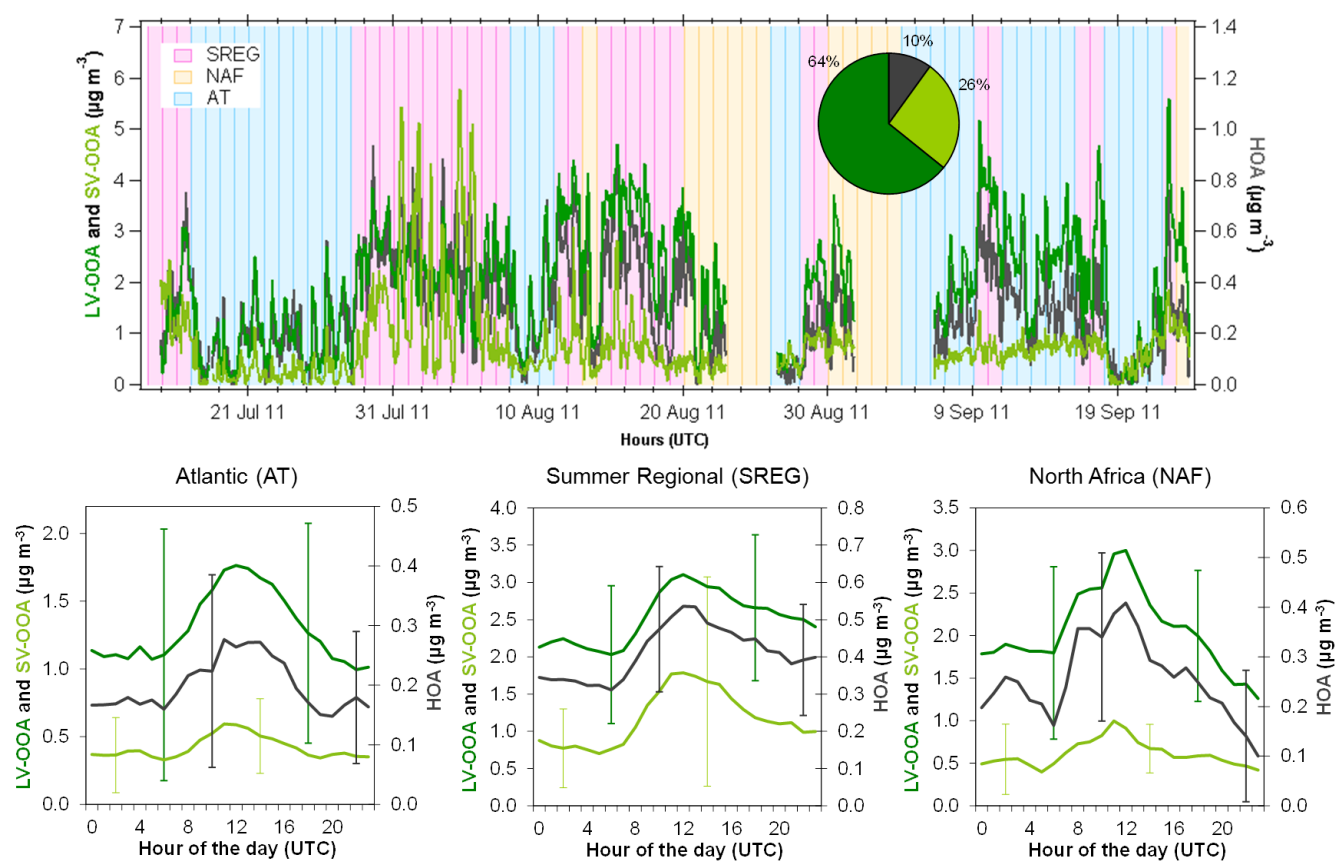

Figure 8. Top: time series of organic species (hydrocarbon-like organic aerosol (HOA), semivolatile oxygenated organic aerosol (SV-OOA) and low-volatility oxygenated organic aerosol (LV-OOA)) concentrations in summer (14 July 2011-24 September 2011). Background colors correspond to daily classification of atmospheric episodes and the pie chart correspond to the average organic species composition for the summer period. Bottom: diurnal cycles of organic species concentrations averaged as a function of atmospheric episode for the summer period. Variation bars indicate \pm standard deviation.
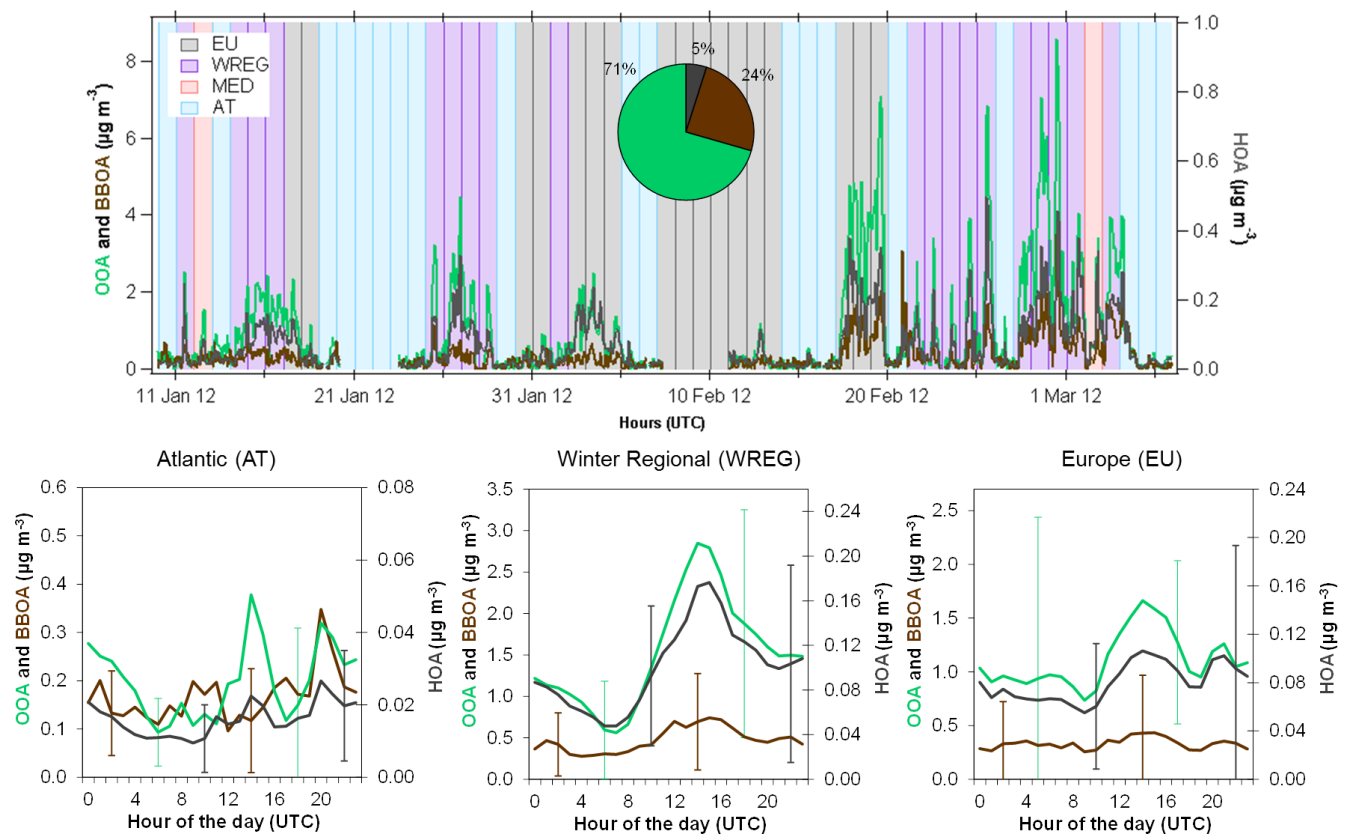

Figure 9. Top: time series of organic species (hydrocarbon-like organic aerosol (HOA), biomass burning organic aerosol (BBOA) and oxygenated organic aerosol (OOA)) concentrations in winter (10 January 2012-7 March 2012). Background colors correspond to daily classification of atmospheric episodes and the pie chart correspond to the average organic species composition for the winter period. Bottom: diurnal cycles of organic species concentrations averaged as a function of atmospheric episode for the winter period. Variation bars indicate \pm standard deviation. 
genated and semivolatile fraction of OOA ( $\mathrm{Ng}$ et al., 2011a) and therefore it has been mostly attributed to SOA formation from more local emissions (Jimenez et al., 2009). For this reason, the LV-OOA and HOA hourly variations are more influenced by long-range transport than those of SV-OOA, which are strongly influenced by local/regional processes. In winter, the maximum concentrations of the OA components were observed simultaneously around 14:00 UTC. The different daily patterns between seasons can be attributed to the higher production of SOA in summer as opposed to winter, when the maximum daily concentrations are reached and later driven by the mountain breezes.

\section{Conclusions}

This work interprets the real-time variation of inorganic and organic submicron components during 10 months (July 2011-April 2012) at a high altitude site in southern Europe (Montsec, $1570 \mathrm{~m}$ a.s.l.). The aerosol chemical composition was obtained with an ACSM, and co-located online and offline $\mathrm{PM}_{1}$ measurements were also carried out. The average concentration of the ACSM plus BC mass during this study was $4.9 \mu \mathrm{g} \mathrm{m}^{-3}$ and, on average, OA was the foremost $\mathrm{PM}_{1}$ constituent (50\%), followed by sulfate $(20 \%)$, nitrate (14\%), ammonium (12\%), BC (4\%) and chloride (1\%). Discrepancies of OA determined by ACSM with co-located measurements pointed to an overestimation by the ACSM probably caused by the use of the default RIE for OA, which could be lower than the actual one. Further research is needed to better address this issue.

The seasonal variation of $\mathrm{PM}_{1}$ mass and chemical component concentrations showed similar patterns, with an increase in summer and a decrease in winter, except for nitrate which has high volatility in summer. The seasonal variation was attributed to the evolution of the PBL height throughout the year and to synoptic circulation and meteorological factors. At MSC the higher temperature and solar radiation in summer enhances the convection processes, incrementing the development of the PBL, and augments atmospheric photochemistry, promoting the formation of secondary inorganic and organic aerosols.

The diurnal variation of $\mathrm{PM}_{1}$ components had no clear diurnal patterns in summer, except for organics. This lack of defined daily patterns was ascribed to the recirculation of air masses that causes the formation of reservoir layers at relatively high altitudes and to the long-range transport from North Africa. These factors result in a high variability of diurnal cycles even within the same type of episode. Nevertheless, organic concentrations had a marked diurnal cycle regardless of the air mass origin, with maximum concentrations around 12:00 UTC. The OA was dominated by LVOOA (64\%), followed by SV-OOA (26\%), and HOA (10\%). Hence, the midday increase with respect to average concen- trations during the night was attributed to the formation of SOA.

In winter, under regional conditions, concentrations of all $\mathrm{PM}_{1}$ components showed much clearer diurnal patterns than in summer, with a maximum between 14:00 and 15:00 UTC. These daily cycles were connected to the fact that MSC is located most of the day within the FT, whereas PBL air masses are only injected upwards after midday. However, when MSC was affected by long-range transport from mainland Europe, less marked daily patterns of $\mathrm{PM}_{1}$ components were observed.

The OA in winter was also mainly secondary $(71 \%)$, with contributions from BBOA (24\%), and HOA (5\%). The hourly variation of these factors showed a clear diurnal pattern regardless of the air mass origin, except for Atlantic advections.

To the authors' knowledge, this is one of the first times that real-time submicron aerosol chemical composition is characterized and its variation interpreted during a period of almost a year in a continental background environment. The results obtained in the present study highlight the importance of the SOA formation processes at a remote site such as MSC, which could be the objective of further investigations.

\section{The Supplement related to this article is available online at doi:10.5194/acp-15-2935-2015-supplement.}

Acknowledgements. This study was supported by the Ministry of Economy and Competitiveness and FEDER funds under the PRISMA (CGL2012-39623-C02-1) and CARIATI (CGL200806294/CLI) projects, and by the Generalitat de Catalunya (AGAUR 2009 SGR8 and the DGQA). The research received funding from the European Union Seventh Framework Programme (FP7/ 2007-2013) ACTRIS under grant agreement no. 262254. We would like to extend their gratitude to the personnel from the COU and the OAdM. We would also like to express our gratitude to the NOAA Air Resources Laboratory (ARL) for the provision of the HYSPLIT transport and dispersion model, and boundary layer height calculation, used in this publication. D. A. Day and J. L. Jimenez thank the DOE (BER/ASR) DE-SC0011105 and NOAA NA13OAR4310063.

Edited by: R. McLaren

\section{References}

Aiken, A. C., Decarlo, P. F., Kroll, J. H., Worsnop, D. R., Huffman, J. A., Docherty, K. S., Ulbrich, I. M., Mohr, C., Kimmel, J. R., Sueper, D., Sun, Y., Zhang, Q., Trimborn, A., Northway, M., Ziemann, P. J., Canagaratna, M. R., Onasch, T. B., Alfarra, M. R., Prevot, A. S. H., Dommen, J., Duplissy, J., Metzger, A., Baltensperger, U., and Jimenez, J. L.: O/C and OM/OC ratios 
of primary, secondary, and ambient organic aerosols with highresolution time-of-flight aerosol mass spectrometry, Environ. Sci. Technol., 42, 4478-4485, doi:10.1021/es703009q, 2008.

Bessagnet, B., Menut, L., Curci, G., Hodzic, A., Guillaume, B., Liousse, C., Moukhtar, S., Pun, B., Seigneur, C., and Schulz, M.: Regional modeling of carbonaceous aerosols over Europe-focus on secondary organic aerosols, J. Atmos. Chem., 61, 175-202, doi:10.1007/s10874-009-9129-2, 2008.

Budisulistiorini, S. H., Canagaratna, M. R., Croteau, P. L., Baumann, K., Edgerton, E. S., Kollman, M. S., Ng, N. L., Verma, V., Shaw, S. L., Knipping, E. M., Worsnop, D. R., Jayne, J. T., Weber, R.J., and Surratt, J. D.: Intercomparison of an Aerosol Chemical Speciation Monitor (ACSM) with ambient fine aerosol measurements in downtown Atlanta, Georgia, Atmos. Meas. Tech., 7, 1929-1941, doi:10.5194/amt-7-1929-2014, 2014.

Budisulistiorini, S. H., Canagaratna, M. R., Croteau, P. L., Marth, W. J., Baumann, K., Edgerton, E. S., Shaw, S. L., Knipping, E. M., Worsnop, D. R., Jayne, J. T., Gold, A. and Surratt, J. D.: Realtime continuous characterization of secondary organic aerosol derived from isoprene epoxydiols in downtown Atlanta, Georgia, using the Aerodyne Aerosol Chemical Speciation Monitor., Environ. Sci. Technol., 47, 5686-5694, doi:10.1021/es400023n, 2013.

Canagaratna, M. R., Onasch, T. B., Wood, E. C., Herndon, S. C., Jayne, J. T., Cross, E. S., Miake-Lye, R. C., Kolb, C. E., and Worsnop, D. R.: Chemical and microphysical characterization of ambient aerosols with the aerodyne aerosol mass spectometer, Wiley Intersci., 26, 185-222, doi:10.1002/mas.20115, 2007.

Canonaco, F., Crippa, M., Slowik, J. G., Baltensperger, U., and Prévôt, A. S. H.: SoFi, an IGOR-based interface for the efficient use of the generalized multilinear engine (ME-2) for the source apportionment: ME-2 application to aerosol mass spectrometer data, Atmos. Meas. Tech., 6, 3649-3661, doi:10.5194/amt6-3649-2013, 2013.

Carbone, S., Saarikoski, S., Frey, A., Reyes, F., Reyes, P., Castillo, M., Gramsch, E., Jayne, J., Worsnop, D. R., and Hillamo, R.: Chemical Characterization of Submicron Aerosol Particles in Santiago de Chile, Aerosol Air Qual. Res., 13, 462-473, doi:10.4209/aaqr.2012.10.0261, 2013.

Carbone, C., Decesari, S., Paglione, M., Giulianelli, L., Rinaldi, M., Marinoni, A., Cristofanelli, P., Didiodato, A., Bonasoni, P., Fuzzi, S., and Facchini, M. C.: 3-year chemical composition of free tropospheric PM1 at the Mt. Cimone GAW global station - South Europe - 2165 m a.s.1., Atmos. Environ., 87, 218-227, doi:10.1016/j.atmosenv.2014.01.048, 2014.

CEN: Air quality - Determination of the $\mathrm{PM}_{10}$ fraction of suspended particulate matter. Reference method and field test procedure to demonstrate reference equivalence of measurement methods, EN12341:1999, 1999.

Chevalier, A., Gheusi, F., Delmas, R., Ordóñez, C., Sarrat, C., Zbinden, R., Thouret, V., Athier, G., and Cousin, J.-M.: Influence of altitude on ozone levels and variability in the lower troposphere: a ground-based study for western Europe over the period 2001-2004, Atmos. Chem. Phys., 7, 4311-4326, doi:10.5194/acp-7-4311-2007, 2007.

Cozic, J., Verheggen, B., Weingartner, E., Crosier, J., Bower, K. N., Flynn, M., Coe, H., Henning, S., Steinbacher, M., Henne, S., Collaud Coen, M., Petzold, A., and Baltensperger, U.: Chemical composition of free tropospheric aerosol for PM1 and coarse mode at the high alpine site Jungfraujoch, Atmos. Chem. Phys., 8, 407-423, doi:10.5194/acp-8-407-2008, 2008.

Crippa, M., Canonaco, F., Lanz, V. A., Äijälä, M., Allan, J. D., Carbone, S., Capes, G., Ceburnis, D., Dall'Osto, M., Day, D. A., DeCarlo, P. F., Ehn, M., Eriksson, A., Freney, E., Hildebrandt Ruiz, L., Hillamo, R., Jimenez, J. L., Junninen, H., Kiendler-Scharr, A., Kortelainen, A.-M., Kulmala, M., Laaksonen, A., Mensah, A. A., Mohr, C., Nemitz, E., O'Dowd, C., Ovadnevaite, J., Pandis, S. N., Petäjä, T., Poulain, L., Saarikoski, S., Sellegri, K., Swietlicki, E., Tiitta, P., Worsnop, D. R., Baltensperger, U., and Prévôt, A. S. H.: Organic aerosol components derived from 25 AMS data sets across Europe using a consistent ME-2 based source apportionment approach, Atmos. Chem. Phys., 14, 61596176, doi:10.5194/acp-14-6159-2014, 2014.

De Gouw, J. and Jimenez, J. L.: Organic aerosols in the Earth's atmosphere., Environ. Sci. Technol., 43, 7614-7618, doi:10.1021/es9006004, 2009.

Donahue, N. M., Robinson, A. L., Trump, E. R., Riipinen, I., and Kroll, J. H.: Volatility and Aging of Atmospheric Organic Aerosol, Top. Curr. Chem., 339, 97-144, doi:10.1007/128_2012_355, 2014.

Elbert, W., Taylor, P. E., Andreae, M. O., and Pöschl, U.: Contribution of fungi to primary biogenic aerosols in the atmosphere: wet and dry discharged spores, carbohydrates, and inorganic ions, Atmos. Chem. Phys., 7, 4569-4588, doi:10.5194/acp-7-4569-2007, 2007.

Freney, E. J., Sellegri, K., Canonaco, F., Boulon, J., Hervo, M., Weigel, R., Pichon, J. M., Colomb, A., Prévôt, A. S. H., and Laj, P.: Seasonal variations in aerosol particle composition at the puy-de-Dôme research station in France, Atmos. Chem. Phys., 11, 13047-13059, doi:10.5194/acp-11-13047-2011, 2011.

Fröhlich, R., Crenn, V., Setyan, A., Belis, C. A., Canonaco, F., Favez, O., Riffault, V., Slowik, J. G., Aas, W., Aijälä, M., Alastuey, A., Artiñano, B., Bonnaire, N., Bozzetti, C., Bressi, M., Carbone, C., Coz, E., Croteau, P. L., Cubison, M. J., Esser-Gietl, J. K., Green, D. C., Gros, V., Heikkinen, L., Herrmann, H., Jayne, J. T., Lunder, C. R., Minguillón, M. C., Moc`nik, G., O’Dowd, C. D., Ovadnevaite, J., Petralia, E., Poulain, L., Priestman, M., Ripoll, A., Sarda-Estève, R., Wiedensohler, A., Baltensperger, U., Sciare, J., and Prévôt, A. S. H.: ACTRIS ACSM intercomparison - Part 2: Intercomparison of ME-2 organic source apportionment results from 15 individual, co-located aerosol mass spectrometers, Atmos. Meas. Tech. Discuss., 8, 1559-1613, doi:10.5194/amtd-8-1559-2015, 2015.

Hallquist, M., Wenger, J. C., Baltensperger, U., Rudich, Y., Simpson, D., Claeys, M., Dommen, J., Donahue, N. M., George, C., Goldstein, A. H., Hamilton, J. F., Herrmann, H., Hoffmann, T., Iinuma, Y., Jang, M., Jenkin, M. E., Jimenez, J. L., Kiendler-Scharr, A., Maenhaut, W., McFiggans, G., Mentel, Th. F., Monod, A., Prévôt, A. S. H., Seinfeld, J. H., Surratt, J. D., Szmigielski, R., and Wildt, J.: The formation, properties and impact of secondary organic aerosol: current and emerging issues, Atmos. Chem. Phys., 9, 5155-5236, doi:10.5194/acp-9-51552009, 2009.

Henne, S., Furger, M., Nyeki, S., Steinbacher, M., Neininger, B., de Wekker, S. F. J., Dommen, J., Spichtinger, N., Stohl, A., and Prévôt, A. S. H.: Quantification of topographic venting of boundary layer air to the free troposphere, Atmos. Chem. Phys., 4, 497509, doi:10.5194/acp-4-497-2004, 2004. 
IPCC 2013 in: Climate Change 2013: The Physical Science Basis (Contribution of Working Group I to the Fifth Assessment Report of the Intergovernmental Panel on Climate Change), edited by: Stocker, T. F., Qin, D., Plattner, G. K., Tignor, M. M. B., Allen, S. K., Boschung, J., Nauels, A., Xia, Y., Bex, V., and Midgley, P. M., Cambridge Univ. Press, UK and New York, USA, 2013.

Jimenez, J. L., Jayne, J. T., Shi, Q., Kolb, C. E., Worsnop, D. R., Yourshaw, I., Seinfeld, J. H., Flagan, R. C., Zhang, X., Smith, K. A., Morris, J. W., and Davidovits, P.: Ambient aerosol sampling using the Aerodyne Aerosol Mass Spectrometer, J. Geophys. Res., 108, 8425, doi:10.1029/2001JD001213, 2003.

Jimenez, J. L., Canagaratna, M. R., Donahue, N. M., Prevot, A. S. H., Zhang, Q., Kroll, J. H., DeCarlo, P. F., Allan, J. D., Coe, H., Ng, N. L., Aiken, A. C., Docherty, K. S., Ulbrich, I. M., Grieshop, A. P., Robinson, A. L., Duplissy, J., Smith, J. D., Wilson, K. R., Lanz, V. A., Hueglin, C., Sun, Y. L., Tian, J., Laaksonen, A., Raatikainen, T., Rautiainen, J., Vaattovaara, P., Ehn, M., Kulmala, M., Tomlinson, J. M., Collins, D. R., Cubison, M. J., Dunlea, E. J., Huffman, J. A., Onasch, T. B., Alfarra, M. R., Williams, P. I., Bower, K., Kondo, Y., Schneider, J., Drewnick, F., Borrmann, S., Weimer, S., Demerjian, K., Salcedo, D., Cottrell, L., Griffin, R., Takami, A., Miyoshi, T., Hatakeyama, S., Shimono, A., Sun, J. Y., Zhang, Y. M., Dzepina, K., Kimmel, J. R., Sueper, D., Jayne, J. T., Herndon, S. C., Trimborn, A. M., Williams, L. R., Wood, E. C., Middlebrook, A. M., Kolb, C. E., Baltensperger, U., and Worsnop, D. R.: Evolution of organic aerosols in the atmosphere., Science, 326, 1525-1529, doi:10.1126/science.1180353, 2009.

Jorba, O., Pandolfi, M., Spada, M., Baldasano, J. M., Pey, J., Alastuey, A., Arnold, D., Sicard, M., Artiñano, B., Revuelta, M. A., and Querol, X.: Overview of the meteorology and transport patterns during the DAURE field campaign and their impact to PM observations, Atmos. Environ., 77, 607-620, doi:10.1016/j.atmosenv.2013.05.040, 2013.

Kroll, J. H. and Seinfeld, J. H.: Chemistry of secondary organic aerosol: Formation and evolution of low-volatility organics in the atmosphere, Atmos. Environ., 42, 3593-3624, doi:10.1016/j.atmosenv.2008.01.003, 2008.

Lang-Yona, N., Rudich, Y., Mentel, Th. F., Bohne, A., Buchholz, A., Kiendler-Scharr, A., Kleist, E., Spindler, C., Tillmann, R., and Wildt, J.: The chemical and microphysical properties of secondary organic aerosols from Holm Oak emissions, Atmos. Chem. Phys., 10, 7253-7265, doi:10.5194/acp-10-7253-2010, 2010.

Lanz, V. A., Prévôt, A. S. H., Alfarra, M. R., Weimer, S., Mohr, C., DeCarlo, P. F., Gianini, M. F. D., Hueglin, C., Schneider, J., Favez, O., D'Anna, B., George, C., and Baltensperger, U.: Characterization of aerosol chemical composition with aerosol mass spectrometry in Central Europe: an overview, Atmos. Chem. Phys., 10, 10453-10471, doi:10.5194/acp-10-10453-2010, 2010.

Middlebrook, A. M., Bahreini, R., Jimenez, J. L., and Canagaratna, M. R.: Evaluation of Composition-Dependent Collection Efficiencies for the Aerodyne Aerosol Mass Spectrometer using Field Data, Aerosol Sci. Technol., 46, 258-271, doi:10.1080/02786826.2011.620041, 2012.

Millan, M. M., Salvador, R., Mantilla, E., and Kallos, G.: Photooxidant dynamics in the Mediterranean basin in summer: Results from European research projects, J. Geophys. Res., 102, 88118823, 1997.
Minguillón, M. C., Perron, N., Querol, X., Szidat, S., Fahrni, S. M., Alastuey, A., Jimenez, J. L., Mohr, C., Ortega, A. M., Day, D. A., Lanz, V. A., Wacker, L., Reche, C., Cusack, M., Amato, F., Kiss, G., Hoffer, A., Decesari, S., Moretti, F., Hillamo, R., Teinilä, K., Seco, R., Peñuelas, J., Metzger, A., Schallhart, S., Müller, M., Hansel, A., Burkhart, J. F., Baltensperger, U., and Prévôt, A. S. H.: Fossil versus contemporary sources of fine elemental and organic carbonaceous particulate matter during the DAURE campaign in Northeast Spain, Atmos. Chem. Phys., 11, 12067-12084, doi:10.5194/acp-11-12067-2011, 2011.

Minguillón, M. C., Ripoll, A., Pérez, N., Prévôt, A. S. H., Canonaco, F., Querol, X., and Alastuey, A.: Chemical characterization of submicron regional background aerosols in the Western Mediterranean using an Aerosol Chemical Speciation Monitor, Atmos. Chem. Phys. Discuss., 15, 965-1000, doi:10.5194/acpd15-965-2015, 2015.

Müller, T., Henzing, J. S., de Leeuw, G., Wiedensohler, A., Alastuey, A., Angelov, H., Bizjak, M., Collaud Coen, M., Engström, J. E., Gruening, C., Hillamo, R., Hoffer, A., Imre, K., Ivanow, P., Jennings, G., Sun, J. Y., Kalivitis, N., Karlsson, H., Komppula, M., Laj, P., Li, S.-M., Lunder, C., Marinoni, A., Martins dos Santos, S., Moerman, M., Nowak, A., Ogren, J. A., Petzold, A., Pichon, J. M., Rodriquez, S., Sharma, S., Sheridan, P. J., Teinilä, K., Tuch, T., Viana, M., Virkkula, A., Weingartner, E., Wilhelm, R., and Wang, Y. Q.: Characterization and intercomparison of aerosol absorption photometers: result of two intercomparison workshops, Atmos. Meas. Tech., 4, 245-268, doi:10.5194/amt-4-245-2011, 2011.

Ng, N. L., Canagaratna, M. R., Zhang, Q., Jimenez, J. L., Tian, J., Ulbrich, I. M., Kroll, J. H., Docherty, K. S., Chhabra, P. S., Bahreini, R., Murphy, S. M., Seinfeld, J. H., Hildebrandt, L., Donahue, N. M., DeCarlo, P. F., Lanz, V. A., Prévôt, A. S. H., Dinar, E., Rudich, Y., and Worsnop, D. R.: Organic aerosol components observed in Northern Hemispheric datasets from Aerosol Mass Spectrometry, Atmos. Chem. Phys., 10, 46254641, doi:10.5194/acp-10-4625-2010, 2010.

Ng, N. L., Canagaratna, M. R., Jimenez, J. L., Chhabra, P. S., Seinfeld, J. H., and Worsnop, D. R.: Changes in organic aerosol composition with aging inferred from aerosol mass spectra, Atmos. Chem. Phys., 11, 6465-6474, doi:10.5194/acp-11-64652011, 2011a.

Ng, N. L., Canagaratna, M. R., Jimenez, J. L., Zhang, Q., Ulbrich, I. M., and Worsnop, D. R.: Real-Time Methods for Estimating Organic Component Mass Concentrations from Aerosol Mass Spectrometer Data, Environ. Sci. Technol., 45, 910-916, doi:10.1021/es102951k, $2011 \mathrm{~b}$.

Ng, N. L., Herndon, S. C., Trimborn, A., Canagaratna, M. R., Croteau, P. L., Onasch, T. B., Sueper, D., Worsnop, D. R., Zhang, Q., Sun, Y. L., and Jayne, J. T.: An Aerosol Chemical Speciation Monitor (ACSM) for routine monitoring of the composition and mass concentrations of ambient aerosol, Aerosol Sci. Technol., 45, 780-794, doi:10.1080/02786826.2011.560211, 2011c.

Paasonen, P., Asmi, A., Petäjä, T., Kajos, M. K., Äijälä, M., Junninen, H., Holst, T., Abbatt, J. P. D., Arneth, A., Birmili, W., van der Gon, H. D., Hamed, A., Hoffer, A., Laakso, L., Laaksonen, A., Richard Leaitch, W., Plass-Dülmer, C., Pryor, S. C., Räisänen, P., Swietlicki, E., Wiedensohler, A., Worsnop, D. R., Kerminen, V.-M., and Kulmala, M.: Warming-induced increase in 
aerosol number concentration likely to moderate climate change, Nat. Geosci., 6, 438-442, doi:10.1038/ngeo1800, 2013.

Paatero, P.: The multilinear engine - a table-driven, least squares program for solving multilinear problems, including the n-way parallel factor analysis model, J. Comput. Graph. Stat., 8, 854888, doi:10.2307/1390831, 1999.

Pandolfi, M., Querol, X., Alastuey, A., Jimenez, J. L., Jorba, O., Day, D., Ortega, A., Cubison, M. J., Comerón, A., Sicard, M., Mohr, C., Prévôt, A. S. H., Minguillón, M. C., Pey, J., Baldasano, J. M., Burkhart, J. F., Seco, R., Peñuelas, J., van Drooge, B. L., Artiñano, B., Di Marco, C., Nemitz, E., Schallhart, S., Metzger, A., Hansel, A., Lorente, J., Ng, S., Jayne, J., and Szidat, S.: Effects of sources and meteorology on particulate matter in the Western Mediterranean Basin: An overview of the DAURE campaign, J. Geophys. Res. Atmos., 119, 4978-5010, doi:10.1002/2013JD021079, 2014a.

Pandolfi, M., Ripoll, A., Querol, X., and Alastuey, A.: Climatology of aerosol optical properties and black carbon mass absorption cross section at a remote high-altitude site in the western Mediterranean Basin, Atmos. Chem. Phys., 14, 6443-6460, doi:10.5194/acp-14-6443-2014, 2014b.

Petit, J.-E., Favez, O., Sciare, J., Crenn, V., Sarda-Estève, R., Bonnaire, N., Moc`(nik, G., Dupont, J.-C., Haeffelin, M., and LeozGarziandia, E.: Two years of near real-time chemical composition of submicron aerosols in the region of Paris using an Aerosol Chemical Speciation Monitor (ACSm) and a multi-wavelength Aethalometer, Atmos. Chem. Phys. Discuss., 14, 24221-24271, doi:10.5194/acpd-14-24221-2014, 2014.

Petzold, A. and Schönlinner, M.: Multi-angle absorption photometry - a new method for the measurement of aerosol light absorption and atmospheric black carbon, J. Aerosol Sci., 35, 421-441, doi:10.1016/j.jaerosci.2003.09.005, 2004.

Petzold, A., Ogren, J. A., Fiebig, M., Laj, P., Li, S.-M., Baltensperger, U., Holzer-Popp, T., Kinne, S., Pappalardo, G., Sugimoto, N., Wehrli, C., Wiedensohler, A., and Zhang, X.-Y.: Recommendations for reporting "black carbon" measurements, Atmos. Chem. Phys., 13, 8365-8379, doi:10.5194/acp-13-83652013, 2013.

Pey, J., Pérez, N., Castillo, S., Viana, M., Moreno, T., Pandolfi, M., López-Sebastián, J. M., Alastuey, A., and Querol, X.: Geochemistry of regional background aerosols in the Western Mediterranean, Atmos. Res., 94, 422-435, doi:10.1016/j.atmosres.2009.07.001, 2009.

Pey, J., Querol, X., Alastuey, A., Forastiere, F., and Stafoggia, M.: African dust outbreaks over the Mediterranean Basin during 2001-2011: $\mathrm{PM}_{10}$ concentrations, phenomenology and trends, and its relation with synoptic and mesoscale meteorology, Atmos. Chem. Phys., 13, 1395-1410, doi:10.5194/acp-13-13952013, 2013.

Querol, X., Alastuey, A., Lopez-soler, A., Plana, F., and Puicercus, J. A.: Daily evolution of sulphate aerosols in a rural area, northeastern Spain - elucidation of an atmospheric reservoir effect, Environ. Pollut., 105, 397-407, doi:10.1016/S02697491(99)00037-8, 1999.

Querol, X., Alastuey, A., Pey, J., Cusack, M., Pérez, N., Mihalopoulos, N., Theodosi, C., Gerasopoulos, E., Kubilay, N., and Koçak, M.: Variability in regional background aerosols within the Mediterranean, Atmos. Chem. Phys., 9, 4575-4591, doi:10.5194/acp-9-4575-2009, 2009.
Raatikainen, T., Vaattovaara, P., Tiitta, P., Miettinen, P., Rautiainen, J., Ehn, M., Kulmala, M., Laaksonen, A., and Worsnop, D. R.: Physicochemical properties and origin of organic groups detected in boreal forest using an aerosol mass spectrometer, Atmos. Chem. Phys., 10, 2063-2077, doi:10.5194/acp-10-20632010, 2010.

Ripoll, A., Pey, J., Minguillón, M. C., Pérez, N., Pandolfi, M., Querol, X., and Alastuey, A.: Three years of aerosol mass, black carbon and particle number concentrations at Montsec (southern Pyrenees, 1570 ma.s.1.), Atmos. Chem. Phys., 14, 4279-4295, doi:10.5194/acp-14-4279-2014, 2014.

Ripoll, A., Minguillón, M. C., Pey, J., Pérez, N., Querol, X., and Alastuey, A.: Joint analysis of continental and regional background environments in the western Mediterranean: $\mathrm{PM}_{1}$ and $\mathrm{PM}_{10}$ concentrations and composition, Atmos. Chem. Phys., 15, 1129-1145, doi:10.5194/acp-15-1129-2015, 2015.

Robinson, A. L., Donahue, N. M., Shrivastava, M. K., Weitkamp, E. A., Sage, A. M., Grieshop, A. P., Lane, T. E., Pierce, J. R., and Pandis, S. N.: Rethinking organic aerosols: semivolatile emissions and photochemical aging., Science, 315, 1259-1262, doi:10.1126/science.1133061, 2007.

Rodríguez, S., Querol, X., Alastuey, A., Kallos, G., and Kakaliagou, O.: Saharan dust contributions to $\mathrm{PM}_{10}$ and TSP levels in Southern and Eastern Spain, Atmos. Environ., 35, 2433-2447, doi:10.1016/S1352-2310(00)00496-9, 2001.

Rodriguez, S., Querol, X., Alastuey, A., and Mantilla, E.: Origin of high summer PM10 and TSP concentrations at rural sites in Eastern Spain, Atmos. Environ., 36, 3101-3112, doi:10.1016/S13522310(02)00256-X, 2002.

Rodríguez, S., Querol, X., Alastuey, A., Viana, M.-M., and Mantilla, E.: Events affecting levels and seasonal evolution of airborne particulate matter concentrations in the Western Mediterranean., Environ. Sci. Technol., 37, 216-222, doi:10.1021/es020106p, 2003.

Salcedo, D., Onasch, T. B., Dzepina, K., Canagaratna, M. R., Zhang, Q., Huffman, J. A., DeCarlo, P. F., Jayne, J. T., Mortimer, P., Worsnop, D. R., Kolb, C. E., Johnson, K. S., Zuberi, B., Marr, L. C., Volkamer, R., Molina, L. T., Molina, M. J., Cardenas, B., Bernabé, R. M., Márquez, C., Gaffney, J. S., Marley, N. A., Laskin, A., Shutthanandan, V., Xie, Y., Brune, W., Lesher, R., Shirley, T., and Jimenez, J. L.: Characterization of ambient aerosols in Mexico City during the MCMA-2003 campaign with Aerosol Mass Spectrometry: results from the CENICA Supersite, Atmos. Chem. Phys., 6, 925-946, doi:10.5194/acp-6-925-2006, 2006.

Schaap, M., Spindler, G., Schulz, M., Acker, K., Maenhaut, W., Berner, A., Wieprecht, W., Streit, N., Müller, K., Brüggemann, E., Chi, X., Putaud, J.-P., Hitzenberger, R., Puxbaum, H., Baltensperger, U., and ten Brink, H.: Artefacts in the sampling of nitrate studied in the "INTERCOMP" campaigns of EUROTRAC-AEROSOL, Atmos. Environ., 38, 6487-6496, doi:10.1016/j.atmosenv.2004.08.026, 2004.

Seco, R., Peñuelas, J., Filella, I., Llusià, J., Molowny-Horas, R., Schallhart, S., Metzger, A., Müller, M., and Hansel, A.: Contrasting winter and summer VOC mixing ratios at a forest site in the Western Mediterranean Basin: the effect of local biogenic emissions, Atmos. Chem. Phys., 11, 13161-13179, doi:10.5194/acp11-13161-2011, 2011. 
Sicard, M., Rocadenbosch, F., Reba, M. N. M., Comerón, A., Tomás, S., García-Vízcaino, D., Batet, O., Barrios, R., Kumar, D., and Baldasano, J. M.: Seasonal variability of aerosol optical properties observed by means of a Raman lidar at an EARLINET site over Northeastern Spain, Atmos. Chem. Phys., 11, 175-190, doi:10.5194/acp-11-175-2011, 2011.

Steinbrecher, R., Smiatek, G., Köble, R., Seufert, G., Theloke, J., Hauff, K., Ciccioli, P., Vautard, R., and Curci, G.: Intra- and inter-annual variability of VOC emissions from natural and seminatural vegetation in Europe and neighbouring countries, Atmos. Environ., 43, 1380-1391, doi:10.1016/j.atmosenv.2008.09.072, 2009.

Sun, Y., Wang, Z., Dong, H., Yang, T., Li, J., Pan, X., Chen, P., and Jayne, J. T.: Characterization of summer organic and inorganic aerosols in Beijing, China with an Aerosol Chemical Speciation Monitor, Atmos. Environ., 51, 250-259, doi:10.1016/j.atmosenv.2012.01.013, 2012.

Takahama, S., Schwartz, R. E., Russell, L. M., Macdonald, A. M., Sharma, S., and Leaitch, W. R.: Organic functional groups in aerosol particles from burning and non-burning forest emissions at a high-elevation mountain site, Atmos. Chem. Phys., 11, 6367-6386, doi:10.5194/acp-11-6367-2011, 2011.

Tiitta, P., Vakkari, V., Croteau, P., Beukes, J. P., van Zyl, P. G., Josipovic, M., Venter, A. D., Jaars, K., Pienaar, J. J., Ng, N. L., Canagaratna, M. R., Jayne, J. T., Kerminen, V.-M., Kokkola, H., Kulmala, M., Laaksonen, A., Worsnop, D. R., and Laakso, L.: Chemical composition, main sources and temporal variability of $\mathrm{PM}_{1}$ aerosols in southern African grassland, Atmos. Chem. Phys., 14, 1909-1927, doi:10.5194/acp-14-1909-2014, 2014.
Tositti, L., Riccio, A., Sandrini, S., Brattich, E., Baldacci, D., Parmeggiani, S., Cristofanelli, P., and Bonasoni, P.: Shortterm climatology of PM10 at a high altitude background station in southern Europe, Atmos. Environ., 65, 142-152, doi:10.1016/j.atmosenv.2012.10.051, 2013.

Volkamer, R., Jimenez, J. L., San Martini, F., Dzepina, K., Zhang, Q., Salcedo, D., Molina, L. T., Worsnop, D. R., and Molina, M. J.: Secondary organic aerosol formation from anthropogenic air pollution: Rapid and higher than expected, Geophys. Res. Lett., 33, L17811, doi:10.1029/2006GL026899, 2006.

Zhang, Q., Worsnop, D. R., Canagaratna, M. R., and Jimenez, J. L.: Hydrocarbon-like and oxygenated organic aerosols in Pittsburgh: insights into sources and processes of organic aerosols, Atmos. Chem. Phys., 5, 3289-3311, doi:10.5194/acp-5-32892005, 2005.

Zhang, Q., Jimenez, J. L., Canagaratna, M. R., Allan, J. D., Coe, H., Ulbrich, I., Alfarra, M. R., Takami, A., Middlebrook, a. M., Sun, Y. L., Dzepina, K., Dunlea, E., Docherty, K., DeCarlo, P. F., Salcedo, D., Onasch, T., Jayne, J. T., Miyoshi, T., Shimono, A., Hatakeyama, S., Takegawa, N., Kondo, Y., Schneider, J., Drewnick, F., Borrmann, S., Weimer, S., Demerjian, K., Williams, P., Bower, K., Bahreini, R., Cottrell, L., Griffin, R. J., Rautiainen, J., Sun, J. Y., Zhang, Y. M., and Worsnop, D. R.: Ubiquity and dominance of oxygenated species in organic aerosols in anthropogenically-influenced Northern Hemisphere midlatitudes, Geophys. Res. Lett., 34, L13801, doi:10.1029/2007GL029979, 2007.

Zhuang, H., Chan, C. K., Fang, M., and Wexler, A. S.: Size distributions of particulate sulfate, nitrate, and ammonium at a coastal site in Hong Kong, Atmos. Environ., 33, 843-853, doi:10.1016/S1352-2310(98)00305-7, 1999. 